Ks. Grzegorz M. BARAN*

\title{
CZWARTA KSIĘGA MACHABEJSKA TŁEM MOWY XV ŚW. GRZEGORZA Z NAZJANZU
}

Wymieniona w tytule artykułu Mowa XV św. Grzegorza w wersji grec-

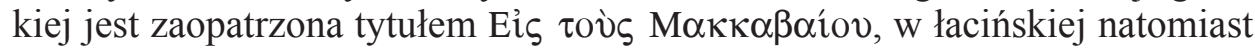
- In Machabaeorum laudem. Zatem mowa ta jest pochwałą wygłoszoną na cześć Machabejczyków, a dokładnie mówiąc - na cześć męczenników machabejskich: kapłana Eleazara, siedmiu braci i ich matki, którzy ponieśli śmierć w czasie prześladowań za czasów Antiocha IV Epifanesa ${ }^{1}$. Trudno określić z całkowitą pewnością - jak zaznaczył redaktor Patrologia Graeca w krótkim wstępie do tejże mowy - kiedy i gdzie została ona wygłoszona przez św. Grzegorza $^{2}$. Tadeusz Sinko wysuwa tezę, że mowa ta mogła powstać w roku 365, czyli w początkowym okresie prześladowań cesarza Walensa ${ }^{3}$. Jan Maria Szymusiak stwierdza natomiast, że została ona wygłoszona ok. czerwca 362 r., w początkowym okresie kapłańskiej posługi św. Grzegorza, kiedy to - po objęciu władzy przez cesarza Juliana Apostatę i ogłoszeniu przez niego edyktu o reformie nauczania (17 VI 362) - miały miejsce niepokoje oraz rozruchy, jakie wszczęła ludność pogańska wobec chrześcijan. Wówczas to - a nie jak sugeruje T. Sinko, że za czasów Walensa - stolica Kapadocji Cezarea utraciła prawa miejskie, a kościoły w Nazjanzie miały być zamknięte, duchowieństwo cezarejskie zaś zostało wcielone do legionów rzymskich ${ }^{4}$.

$\mathrm{Z}$ samego tekstu mowy, co zostało wyrażone już w drugim zdaniu, jasno wynika, że św. Grzegorz wygłosił ją w dniu odbywających się uroczysto-

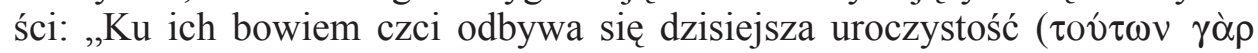

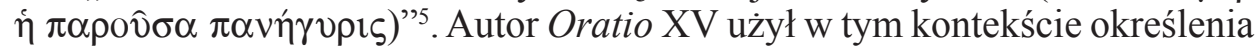

${ }^{*}$ Ks. dr Grzegorz M. Baran - adiunkt w Katedrze Retoryki w Instytucie Kulturoznawstwa na Wydziale Filozofii Katolickiego Uniwersytetu Lubelskiego Jana Pawła II; e-mail: mariusz.grzegorz@wp.pl.

${ }^{1} \mathrm{Na}$ temat wybuchu prześladowań i męczeństwa męczenników machabejskich zob. np. G.M. Baran, The Jewish Community and the Hellenistic Culture in the Light of the Books of the Maccabees, „Teologia i Człowiek” 25 (2014) nr 1, 61-63 i 74-77.

${ }^{2}$ Por. Monitum in Orationem XV, PG 35, 911-912.

${ }^{3}$ Por. T. Sinko, De Gregorii Nazianzei Laudibus Machabaeorum, „Eos” 13 (1907) 28-29.

${ }^{4}$ Por. J.M. Szymusiak, Grzegorz Teolog. Uźródet chrześcijańskiej myśli IV wieku, Poznań 1965, 122-123 i 598; Święty Grzegorz z Nazjanzu. Mowy wybrane, red. S. Kazikowski, Warszawa 1967, 15.

${ }^{5}$ Gregorius Nazianzenus, Oratio XV 1, PG 35, 912, tłum. A. Grużewski: Mowa 15: Pochwata Machabejczyków, w: Szymusiak, Grzegorz Teolog, s. 315. 
$\pi \alpha v i ́ \gamma v \rho ı \varsigma$ - „uroczyste zgromadzenie, zebranie świąteczne całego ludu”, a dookreślając tę uroczystość imiesłowem $\pi \alpha \rho 0 \hat{\sigma} \sigma \alpha$, chciał niejako zaznaczyć, że odbywała się ona właśnie w dniu, kiedy on wygłaszał swoją mowę. $\mathrm{Z}$ przekazów historycznych wiadomo (por. $2 \mathrm{Mch} 6,18-7,42)^{7}$, że męczennicy machabejscy byli zasadniczo męczennikami żydowskimi, którzy oddali życie w imię wierności nakazom Prawa Mojżeszowego. Czczeni byli jednak zarówno przez Żydów, jak i przez chrześcijan. Przemawia za tym kilka starożytnych dokumentów: średniowieczna judeo-arabska księga „Farag”, autorstwa Nissim ibn Shahin z Kairowan; arabski opis topograficzny Antiochii z ok. VI w.; wzmianka bizantyńskiego chronografa z VI w.; syryjskie martyrologium z Edessy, datowane na 412 r.; Sermo in solemnitate martyrum Machabaeorum św. Augustyna (Mowa 300), skomponowana po 391 r.; In sanctos Maccabaeos homilia św. Jana Chryzostoma $(1,1)$ także jego De sanctis martyribus sermo (1), pochodzące z lat 386-398; oraz omawiana właśnie tutaj mowa św. Grzegorza z Nazjanzu ${ }^{8}$.

Z przywołanych świadectw wynika zatem, że w Antiochii istniał dość mocny kult owych męczenników. Trudno jednak orzec, czy istniały w Antiochii miejsca, w których znajdowały się jakieś doczesne szczątki męczenników (relikwie), czy były to tylko symboliczne miejsca, gdzie corocznie celebrowano rocznicowe obchody ${ }^{9}$. Należy zaznaczyć, że do dziś w Martyrologium Romanum pod datą 1 sierpnia znajduje się notka na temat wspomnienia męczenników machabejskich ${ }^{10}$.

Jak wynika z analizy treści Oratio XV, św. Grzegorz - komponując ją - miał prawdopodobnie przed oczyma nie tylko opisy męczeńskich śmierci Machabejczyków, znanych przede wszystkim z kanonicznej 2Mch, ale również - a może przede wszystkim - przekaz zawarty w Czwartej Księdze

${ }^{6}$ Znaczenie słów greckich podawane jest za: Słownik grecko-polski, t. 1-4, red. Z. Abramowiczówna, Warszawa 1958-1965; O. Jurewicz, Stownik grecko-polski, t. 1-2, Warszawa 2000-2001.

${ }^{7}$ Druga Księga Machabejska należy do ksiąg historycznych Starego Testamentu, por. E. Zawiszewski, Księgi Machabejskie, w: Wstęp do Starego Testamentu, red. L. Stachowiak, Poznań 1990, 231-233.

${ }^{8}$ Źródła te omawia S.A. Cummins, Paul and Crucified Christ in Antioch. Maccabean Martyrdom and Galatians 1 and 2, Society for New Testament Studies. Monograph Series 114, Cambridge 2004, 84-85.

${ }^{9}$ Por. Gregorius Nazianzenus, Oratio XV 2, PG 35, 913. Zob. J. Oberman, The Sepulchre of the Maccabean Martyrs, JBL 50 (1931) 261-265.

${ }^{10}$ Por. Martyrologium Romanum. Ex Decreto Sacrosncti Oecumenici Concilii Vaticani II Instauratur Auctoritate Ioannis Pauli PP II Promulgatum. Editio Typica, Typis Vaticanis 2001, 405: „Commemoratio passionis sanctorum septem fratrum martyrum, qui Antiochiae in Syria, sub Antiocho Epiphane rege, propter legem Domini invicta fide servatam, morti crudeliter traditi sunt cum matre sua, in singulis quidem filiis passa, sed in omnibus coronata, sicut in secundo libro Machabaeorum narratur. Item commemoratur sanctus Eleazarus, unus de primoribus scribarum, vir aetate provectus, qui in eadem persecutione, illicitam carnem manducare propter vitae amorem respuens, gloriosissimam mortem magis quam odiosam vitam complectens, voluntarie praeivit ad supplicium, magnum virtutis relinquens exemplum". 
Machabejskiej $(4 \mathrm{Mch})^{11}$, która również zawiera relacje na temat męczenników machabejskich, ale $\mathrm{w}$ nieco rozbudowanej formie.

Przystępując do wykazania słuszności tezy postawionej w tytule artykułu, warto jeszcze powiedzieć kilka słów na temat samej 4Mch. Przede wszystkim należy zaznaczyć, że przynależy ona do pism apokryficznych ${ }^{12}$. Cieszyła się jednak dość dużym autorytetem, ponieważ już w starożytności została włączona w corpus wielu rękopisów LXX (np. synajski z IV w. i aleksandryjski z V w., a także Venetus Graecus z VIII-IX wieku' ${ }^{13}$ ). Jak zostało wyżej zaznaczone, 4Mch zawiera te same motywy, co $2 \mathrm{Mch}$, stąd też istnieje pogląd, że $2 \mathrm{Mch}$ była bezpośrednim źródłem dla $4 \mathrm{Mch}$, lub też obie księgi powstały niezależnie, przy czym ich autorzy korzystali z tego samego materiału ${ }^{14}$. Czas powstania księgi jest trudny do ustalenia, stąd też uczeni - opierając się na tak zwanych kryteriach wewnętrznych - podają różne rozwiązania: jedni uważają, że 4Mch powstała w 1. poł. I w. po Chr. ${ }^{15}$, drudzy natomiast, że pomiędzy 90 a 100 r. po Chr. ${ }^{16}$, inni jeszcze, że została skomponowana w ciagu pierwszych trzydziestu lat II w. po Chrystusie ${ }^{17}$. Trudne jest także określenie miejsca powstania 4Mch: prawdopodobnie powstała w środowisku diaspory żydowskiej w Antiochii nad Orontesem, lub też w bliskim związku z tym środowiskiem ${ }^{18}$. Jej autorem był bliżej nieznany Żyd, który w świetle księgi jawi się jako człowiek pobożny, a zarazem ortodoksyjny, czego wyrazem jest jego widoczna troska o przestrzeganie wymogów judaizmu. Niewątpliwie - co również wynika z treści 4Mch - posiadał on gruntowną znajomość tekstów oraz teologii Starego Testamentu; był także człowiekiem starannie wykształconym w filozofii i retoryce greckiej ${ }^{19}$. Swoje dzieło autor 4Mch skomponował w języku greckim, którego kunszt świadczy, że dla niego ów język był rodzimy ${ }^{20}$.

${ }^{11} \mathrm{~W}$ niniejszym opracowaniu korzystano z wydania krytycznego i przekładu polskiego 4Mch: Machabaeorum IV, ed. A. Rahlfs, w: Septuaginta. Id est Vetus Testamentum graece iuxta LXX interpretes, t. 1, Stuttgart 1979, 1157-1184, tłum. M. Wojciechowski: Czwarta Księga Machabejska, w: M. Wojciechowski, Apokryfy z Biblii greckiej. 3 i 4 Księga Machabejska, 3 Księga Ezdrasza, oraz Psalm 151 i Modlitwa Manassesa, Rozprawy i Studia Biblijne 8, Warszawa 2001, 123-200.

${ }^{12}$ Por. Wojciechowski, Apokryfy z Biblii greckiej, s. 110.

${ }^{13}$ Por. H.J. Klauck, 4. Makkabäerbuch, Jüdische Schriften aus hellenistisch-römischer Zeit III/6, Gütersloh 1989, 678.

${ }^{14}$ Por. D.A. de Silva, 4 Maccabees, Guides to Apocrypha and Pseudepigrapha, Sheffield 1998, 28-29; Klauck, 4. Makkabäerbuch, s. 654-657; Wojciechowski, Apokryfy z Biblii greckiej, s. $102-102$.

${ }^{15}$ Por. De Silva, 4 Maccabees, s. 18.

${ }^{16}$ Por. Klauck, 4. Makkabäerbuch, s. 669.

${ }^{17}$ Por. U. Breitenstein, Beobachtungen zu Sprache, Stile und Gedankengut des Vierten Makkabäerbuchs, Basel - Stuttgart 1976, 174-175.

${ }^{18}$ Por. M. Hadas, The Third and Fourth Books of Maccabees, Jewish Apocryphal Literature, New York 1953, 110-113; por. De Silva, 4 Maccabees, s. 19-21.

${ }^{19}$ Por. De Silva, 4 Maccabees, s. 12-14; Hadas, The Third and Fourth Books of Maccabees, s. $115-118$.

${ }^{20}$ Por. De Silva, 4 Maccabees, s. 12. 
Teksty Starego Testamentu znał zatem jedynie z LXX, o czym świadczy fakt, że starotestamentalne cytaty przytaczał za LXX ${ }^{21}$.

Niewątpliwie - jak wynika $\mathrm{z}$ analizy tekstu księgi - jest ona dziełem na wskroś przenikniętym duchem kultury greckiej, a dokładnej mówiąc - hellenistycznej. Wyrazem tego jest po pierwsze jej mocno zretoryzowany charakter (uczeni dostrzegają w niej cechy stylu azjańskiego), po drugie - oparcie całego wywodu na filozofii greckiej ${ }^{22}$, po trzecie - bogate spektrum odniesień do greckiej literatury ${ }^{23}$ oraz zastosowana metaforyka zaczerpnięta z kultury greckiej ${ }^{24}$.

Ważną kwestią, o której należy wspomnieć, jest gatunek literacki 4Mch. Uczeni przeprowadzając badania komparatystyczne, wykazali liczne podobieństwa do niektórych gatunków, które występowały w starożytnej literaturze greckiej: zasadniczo dostrzeżono elementy diatryby, jak również mowy pochwalnej ( $\dot{\varepsilon} \gamma \kappa \omega ́ \mu t o v)$, czy też rozprawy protreptycznej ${ }^{25}$. Na szczególną uwagę zasługuje sugestia uczonych, że 4Mch mogła zostać skomponowana na

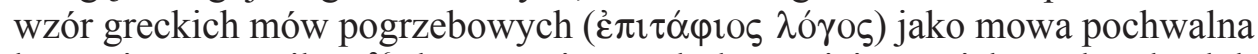
ku czci męczenników ${ }^{26}$, która związana była z miejscem ich pochówku lub rocznicą śmierci ${ }^{27}$. Trudno jednak wykazać, czy mowa ta została rzeczywiście wygłoszona, czy stanowiła jedynie dzieło literackie, przeznaczone do czytania $^{28}$. Należy bowiem podkreślić, że 4 Mch posiada bardzo filozoficzny charakter, o czym świadczy zapowiedź w pierwszych wersetach księgi: „Wysoce filozoficzną podjać mam kwestię, czy pobożny rozum samowładnie panuje nad namiętnościami" (4Mch 1, 1). A zatem głównym zagadnieniem, jakie podjął autor 4Mch, było wykazanie, że pobożny rozum jest w stanie panować nad namiętnościami. Przywołane przykłady męczeńskich śmierci męczenników machabejskich stanowią w całym wywodzie niejako ilustrację $\left(\pi \alpha \rho \alpha \delta \varepsilon^{i} \gamma \mu \alpha \tau \alpha\right)$ prawdziwości postawionej przez autora tezy (por. 4Mch 1, 7-9). Niemniej jednak owe przykłady - jak zaznaczył w dalszej części cytowanej wypowiedzi sam autor - były także dla niego przedmiotem pochwały jako wyraz wielkiej szlachetności, męstwa i wytrwałości:

„Mnie wypada pochwalić cnoty mężów, co w tej porze za szlachetność zginęli z matka, a uhonorowanych chcę głosić jako błogosławionych. Podziwiani

${ }^{21}$ Por. Wojciechowski, Apokryfy z Biblii greckiej, s. 97.

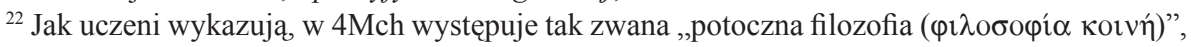
charakterystyczna dla czasów, w których żył autor 4Mch; faktycznie był to stoicyzm wzbogacony elementami innych systemów filozoficznych, por. R. Renehan, The Greek Philosophical Background of Forth Maccabees, „Rheinisches Museum für Philologie” 115 (1972) 223-238; Breitenstein, Beobachtungen zu Sprache, s. 158-167; Wojciechowski, Apokryfy z Biblii greckiej, s. 114.

${ }^{23}$ Por. De Silva, 4 Maccabees, s. 51-124.

${ }^{24}$ Por. Wojciechowski, Apokryfy z Biblii greckiej, s. 105.

${ }^{25}$ Por. Hadas, The Third and Fourth Books of Maccabees, s. 101-103; De Silva, 4 Maccabees, s. $51-124$.

${ }^{26}$ Por. De Silva, 4 Maccabees, s. 47 i 78-79.

${ }^{27}$ Por. Wojciechowski, Apokryfy z Biblii greckiej, s. 100.

${ }^{28}$ Por. Hadas, The Third and Fourth Books of Maccabees, s. 102. 
nie tylko przez wszystkich ludzi za swe męstwo i wytrwałość, lecz również przez swoich katów, przyczynili się do upadku gnębiącej naród tyranii, zwyciężając tyrana wytrwałością, tak że oczyszczona została przez nich ojczyzna. Ale o tym oczywiście będę miał sposobność mówić, poczynając od głównej tezy, jak zwykłem czynić, a tak dotrę do ich sprawy, chwałę oddając przemądremu Bogu" (4Mch 1, 10-12).

Całość zatem dzieła - jakkolwiek mocno filozoficzna - posiada wyraźny element pochwały, a ponadto wymiar parenetyczny, ponieważ zawiera zachętę do naśladowania owych męczenników w wytrwałym, bezkompromisowym przestrzeganiu Prawa, co widać wyraźnie w następującym fragmencie:

„O Abrahamowego nasienia potomkowie, chłopcy izraelscy, podporządkujcie się temu prawu i pod każdym względem bądźcie pobożni, wiedząc, że pobożny rozum jest władcą namiętności, i to nie tylko wewnętrznych, ale i zewnętrznych cierpień" (4Mch 18, 1-2).

Wszystkie wymienione elementy 4Mch, zarówno na płaszczyźnie merytorycznej, jak i formalnej, mogły stanowić wspaniały materiał również dla chrześcijańskich mówców, pragnących zachęcić współwyznawców do wierności Bożym przykazaniom nawet za cenę męczeństwa. W tym celu motywem męczenników machabejskich posłużył się także św. Grzegorz z Nazjanzu, który - zachęcając do oddawania czci męczennikom machabejskim - wzywał swoich słuchaczy, aby również stali się podobnymi bojownikami $\left(\dot{\alpha} \theta \lambda \eta \tau \alpha^{\prime}\right)^{29}$.

Mając na uwadze powyższe treści, będziemy starać się w niniejszym artykule wykazać, że św. Grzegorz przy komponowaniu mowy na cześć męczenników machabejskich zasadniczo inspiracje czerpał z 4Mch. W celu osiągnięcia zamierzonego celu zastosujemy metodę porównawczą, zarówno na płaszczyźnie słownictwa, jak również motywów literacko-teologicznych.

\section{OKREŚLENIE PRZEZ ŚW. GRZEGORZA TEKSTU ŹRÓDŁOWEGO O MĘCZENNIKACH MACHABEJSKICH}

Po zapowiedzeniu tematu mowy oraz wstępnym wyjaśnieniu istoty męczeńskiej śmierci męczenników machabejskich św. Grzegorz przedstawił również tekst źródłowy, z którego - jak zaznaczył - można się dowiedzieć wszystkiego o wspomnianych męczennikach:

„o tym wszystkim pouczy pragnących się dowiedzieć i zadawać sobie trud książka o nich. Tam występuje nauka o tym, jak rozum posiada pełną władzęnad cierpieniami i jak wywiera wpływ na przewagę tych dwóch cech: cnoty i podłości. Autor posłużył się wśród wielu przykładów także ich zmaganiem się" ${ }^{\text {”30 }}$.

\footnotetext{
${ }^{29}$ Por. Gregorius Nazianzenus, Oratio XV 12, PG 35, 933.

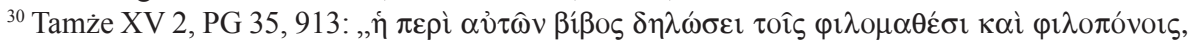


Jak wynika z przytoczonej wypowiedzi, źródłem wiedzy na temat męczenników machabejskich mogła być, według św. Grzegorz, jakaś „księga o nich ( mógłby czerpać wiedzę na temat męczenników machabejskich, powinna być należąca do kanonu biblijnego 2Mch. Jednakże św. Grzegorz nie wymienił jej z tytułu, który w kodeksach LXX brzmi: MAKKABAI $2 N$ B'. Określił natomiast jej zasadniczy cel oraz przedmiot rozważań. Zaznaczył bowiem, że owa księga przedstawia „naukę o tym, jak rozum posiada pełną władzę nad

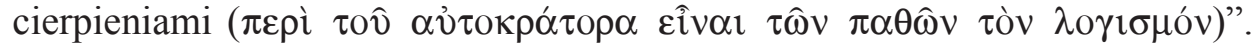
Wzmianka na temat rozumu panującego samowładnie nad cierpieniami, czy dokładniej mówiąc, nad namiętnościami (ze względu na użycie rzeczownika $\pi \alpha ́(\theta o \varsigma)$, przywołuje bezpośrednio zapowiedź tematu 4Mch, którą autor wyraził już w pierwszym zdaniu exordium tejże księgi ${ }^{31}$ :

„Wysoce filozoficzną podjąć mam kwestię, czy pobożny rozum samowładnie

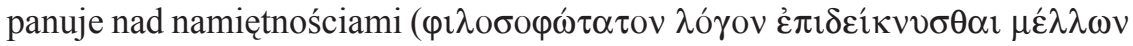

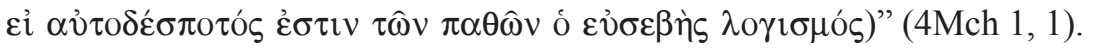

Temat ten niewątpliwie przewija się przez całą 4Mch, o czym świadczy sama

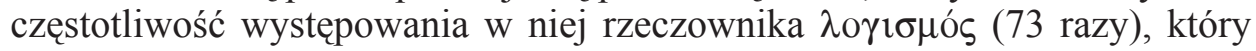
zazwyczaj występuje w kontekstach, gdzie mowa jest o jego panowaniu nad rozmaitymi namiętnościami ${ }^{32}$. Skupiając jednak uwagę na samej zapowiedzi tematu 4Mch, można zauważyć pewną paralelę również na poziomie samego słownictwa, jakim posłużyli się obaj autorzy. Nie jest to pełna zbieżność, gdyż św. Grzegorz posłużył się - jako określeniem rozumu - rzeczownikiem

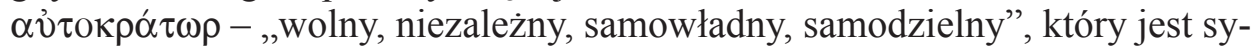

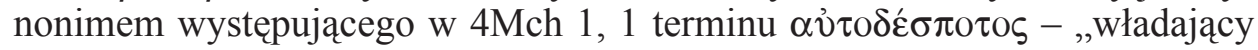

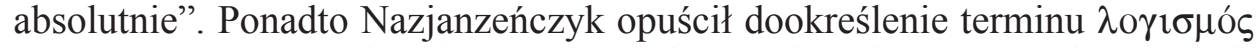
w postaci przymiotnika $\varepsilon \hat{\sigma \varepsilon \varepsilon ß \eta ́ s ~-~ „ p o b o z ̇ n y, ~ b o g o b o j n y ” . ~ A n a l i z u j a ̨ c ~ j e d-~}$ nak 4Mch, można znaleźć również nieco zmodyfikowane frazy, wyrażające zasadniczy temat księgi: „rozum jest samowładcą nad namiętnościami

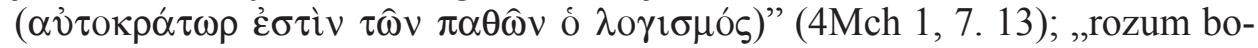

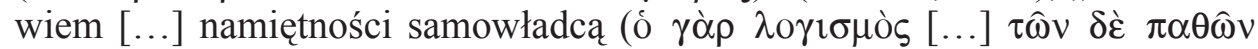

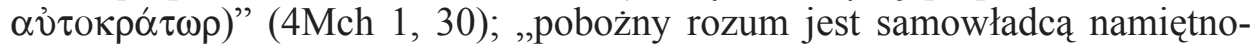

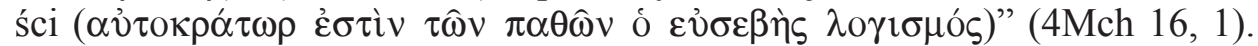
Jak widać na przykładzie przywołanych fraz, zwłaszcza w dwóch pierwszych

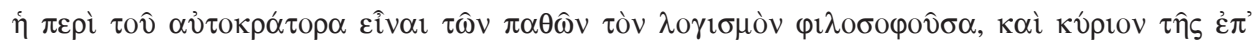

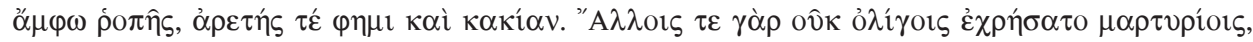

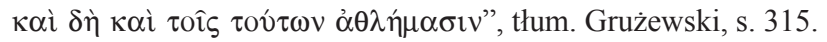

${ }^{31}$ Uczeni zauważają, że 4Mch 1,1-12 posiada cechy exordium greckiej mowy retorycznej, por. H.J. Klauck, Hellenistische Rhetorik im Diasporajudentum. Das Exordium des vierten Makkabäerbuchs (4 Makk 1.1-12), NTS 35 (1989) 451-465.

${ }^{32} \mathrm{~W}$ wielu przypadkach we wspomnianych kontekstach pojawiają się czasowniki: $\kappa \rho \alpha \tau \varepsilon \hat{v} v$

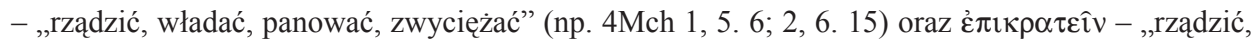
kierować, dowodzić, zwyciężać, stawać się panem" (np. 4Mch 1, 3. 9. 14. 19. 32. 33; 2, 4; 14, 11). 
przypadkach, istnieje bezpośrednia zbieżność na płaszczyźnie słownictwa pomiędzy określeniem tematu 4Mch oraz wspomnianej przez św. Grzegorz owej

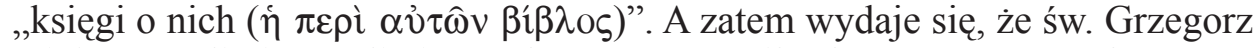
miał na myśli niewątpliwie przekaz o męczennikach zawarty w 4Mch.

W tym miejscu warto wspomnieć, że u dwóch pisarzy starożytnych pojawiają się podobne określenia, które przypisywane są jako tytuł do jednego z dzieł Józefa Flawiusza. Pierwszy z nich to Euzebiusz z Cezarei, który w swej Historia Ecclesiastica podał następującą wzmiankę:

„Józef napisał ponadto inne znakomite dzieło: $O$ potędze rozumu, które inni nazywają: Machabaikon, bowiem zawiera opis walk, które według tak zwanych Ksiag Machabejskich Hebrajczycy dzielnie toczyli w obronie Bożej religii" ${ }^{\prime 33}$.

Drugim autorem jest św. Hieronim, który z kolei w dziele De viris illustribus, opisując postać Józefa Flawiusza podał:

„Inna znowu księga Józefa pod tytułem: Peri Autokratoros logismou bardzo piękna, mówi też o męczeńskich dziejach Machabeuszów"34.

Jak wynika z przytoczonych cytatów, obaj pisarze autorstwo owej księgi przypisywali Józefowi Flawiuszowi. W starożytności było dość powszechne przekonanie, że autorem 4Mch jest Józef Flawiusz ${ }^{35}$, o czym świadczy między innymi fakt, że 4Mch pojawia się w niektórych rękopisach dzieł tegoż historyka żydowskiego ${ }^{36}$. A zatem - w świetle przekazu zarówno Euzebiusza,

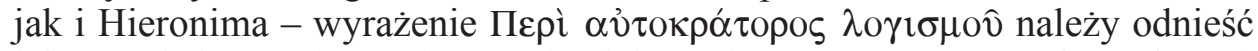
jako tytuł do 4Mch. Stąd też pojawiająca się u św. Grzegorza fraza $\dot{\eta} \pi \varepsilon \rho \grave{i}$

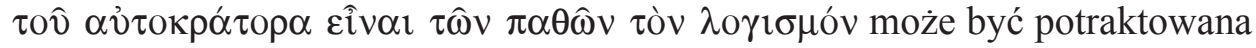
jako modyfikacja tytułu, jaki podali Euzebiusz i Hieronim. Ten argument tym bardziej wzmacnia tezę, że Nazjanzeńczyk wymieniając ową „księgę” o męczennikach machabejskich, miał na uwadze 4Mch.

Poparciem tej tezy może być nadto dalsza część zdania, w której św. Grzegorz określił przedmiot rozważań 4Mch. Użył bowiem stwierdzenia, w którym pojawia się termin $\kappa$ ṕos, który określa rozum jako panujący i nad cnotą, i nad podłością. Tego rodzaju myśl jest natomiast zawarta w 4Mch 1, 30, gdzie mowa jest również o rozumie jako panującym nad cnotą: „Rozum bowiem

${ }^{33}$ Eusebius Caesariensis, HE III 10, 6, ŹMT 70 [wyd. grecko-polskie, oprac. H. Pietras, thum.

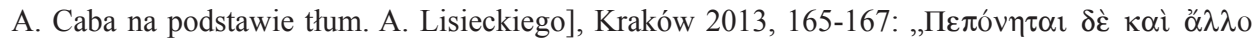

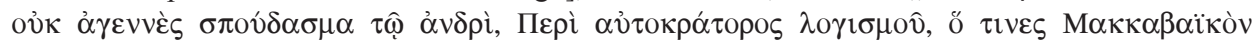

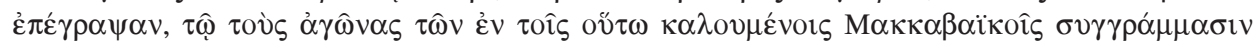

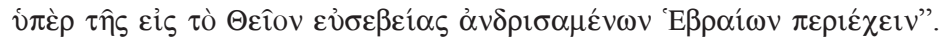

${ }^{34}$ Hieronymus, De viris illustribus 13, PL 23, 629-631: „Alius quoque liber ejus, qui inscribi-

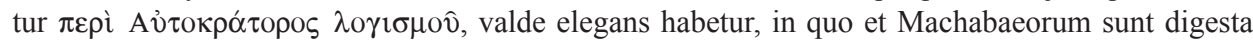
martyria”, tłum. W. Szołdrski: Św. Hieronim, O znakomitych mężach, PSP 6, Warszawa 1970, 41.

${ }^{35}$ Por. C. Kraus Reggiani, 4 Maccabei, Commentario storico ed esegetico all'Antico e al Nuovo Testamento 1, Genova 1992, 11-12.

${ }^{36}$ Por. Klauck, 4. Makkabäerbuch, s. 679. 


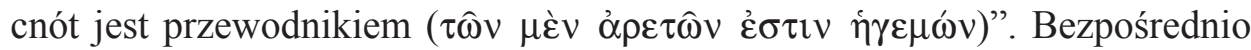

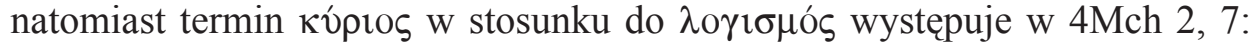

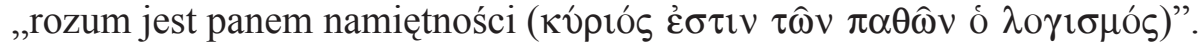

Na uwagę zasługuje również utworzony od czasownika słów czynny czasu teraźniejszego $\varphi \imath \lambda$ ○oopov̂ $\sigma \alpha$, którego św. Grzegorz użył,

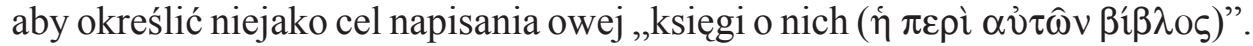
Czasownik ten w połączeniu z przyimkiem $\pi \varepsilon \rho i ́$, jak to jest w tekście Nazjanzeńczyka, oznacza „dążyć do wiedzy, do poznania czegoś”. Na uwagę zasługuje jednak występujący w tym czasowniku rdzeń $\varphi \imath \lambda о \sigma o \varphi-$, który sugeruje, że owe dążenia do wiedzy/poznania mają charakter wysiłków filozoficznych. To zaś budzi bezpośrednie skojarzenie ze stwierdzeniem autora 4Mch, który we wstępie zaznaczył, że rozważania na temat rozumu panującego samowładnie nad namiętnościami są kwestią „wysoce filozoficzną ( $\varphi \imath \lambda o \sigma o \varphi \omega ́ \tau \alpha \tau o \varsigma$

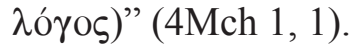

Biorąc pod uwagę tak określony - zarówno na płaszczyźnie merytorycznej, jak i słownictwa - przedmiot oraz sposób rozważań, które zawarte są zdaniem św. Grzegorza - w księdze o męczennikach machabejskich, nie można mieć wątpliwości, że Nazjanzeńczyk miał przed oczyma 4Mch, gdyż autor $2 \mathrm{Mch}$ nie zajmuje się w swej księdze tego rodzaju dywagacjami. W tym kontekście należy zwrócić uwagę na jeszcze jeden szczegół: otóż św. Grzegorz zaznaczył, że autor przywołanego przez niego dzieła o męczennikach machabejskich w celu zobrazowania tezy, że rozum posiada pełną władzę nad namiętnościami, posłużył się wieloma przykładami, pośród których znalazł się opis zmagań męczenników ${ }^{37}$. Tego rodzaju wzmianka tym bardziej potwierdza tezę, że chodzi o 4Mch, gdyż jej autor obok wspomnianych przykładów Eleazara oraz siedmiu braci i ich matki przywołał wiele innych - zwłaszcza pochodzenia biblijnego - przykładów ludzi, którzy kierując się pobożnym rozumem zapanowali nad namiętnościami: np. Józef Egipski (por. 4Mch 2, 1-6); Mojżesz (por. 4Mch 2, 15-18); Dawid (por. 4Mch 3, 6-18); Daniel, Azariasz, Ananiasz i Miszael (por. 4Mch 16, 21).

\section{POWIELENIE NIEŚCISŁOŚCI HISTORYCZNEJ PRZEZ ŚW. GRZEGORZA}

Czytając w 4Mch wzmiankę biograficzną na temat Antiocha IV, można natknąć się na pewną nieścisłość historyczną, jaką popełnił autor 4Mch. Otóż podał on, że Antioch IV był synem króla Seleukosa: „Gdy zaś zmarł król Seleukos, odziedziczył władzę syn jego, Antioch Epifanes” (4Mch 4, 15). Chodziłoby tutaj o Seleukosa IV Filopatora, po którym władzę właśnie przejął Antioch. Jednakże - jak wiadomo z przekazów historycznych - Seleukos IV był starszym bratem Antiocha IV, a nie jego ojcem. Ojcem natomiast obydwu

\footnotetext{
${ }^{37}$ Por. Gregorius Nazianzenus, Oratio XV 2, PG 35, 913.
} 
braci był Antioch III Wielki ${ }^{38}$. Również i św. Grzegorz określił Seleukosa ojcem Antiocha ${ }^{39}$. To by wskazywało, że Nazjanzeńczyk powielił błąd historyczny za autorem $4 \mathrm{Mch}$. W konsekwencji potwierdzałoby to tezę, że komponując swoją mowę, św. Grzegorz opierał się na tekście 4Mch. Jednakże tezę tę można nieco osłabić, ponieważ równie dobrze św. Grzegorz mógł opierać się na tekście 2Mch, gdzie nie ma dokładnie określonych paranteli pomiędzy Antiochem a Seleukosem (por. 2Mch 4, 7). Wzmianka, że Antioch IV objął tron po śmierci Seleukosa, budzi skojarzenie dla kogoś nieobeznanego dokładnie z historią Seleucydów, iż był on sukcesorem swego ojca. Idąc tym tokiem rozumowania, św. Grzegorz mógł ze wspomnianym błędem określić relacje pomiędzy Seleukosem i Antiochem równie dobrze na podstawie 2Mch. Niemniej jednak teza o powieleniu omawianej nieścisłości historycznej za 4Mch jest wysoce prawdopodobna ${ }^{40}$.

\section{ELEMENTY PARALELNE}

Posługując się metodą porównawczą, można dostrzec wiele elementów paralelnych, które łączą Oratio XV z 4Mch. Te paralelizmy - jak zostanie niżej wykazane - pojawiają się na różnych płaszczyznach: na płaszczyźnie używanego słownictwa, opisów oraz różnych motywów (literackich i teologicznych).

1. Zbieżności w prezentacji męczenników i okoliczności ich śmierci. Analizując sposób prezentacji męczenników oraz opis okoliczności ich męczeństwa, można mieć wrażenie, że św. Grzegorz inspirował się tekstem 4Mch. Przedstawimy kilka przykładów, które pozwolą dostrzec pewne paralelizmy.

a) Eleazar. W przypadku Eleazara widać pewne podobieństwa pomiędzy 4Mch oraz Oratio XV już na płaszczyźnie opisujących go określeń. Św. Grzegorz kilka razy nawiązuje do godności kapłańskiej Eleazara ${ }^{41}$, określając go

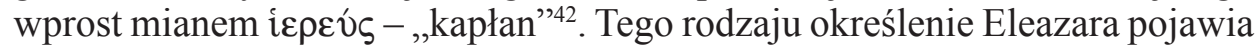
się w 4Mch 5, 4; 7, 6 oraz 17, 9, jak również odniesienia do kapłańskiej godności (por. 4Mch 5, 35; 7,6), brak natomiast takich odniesień w 2Mch. Dru-

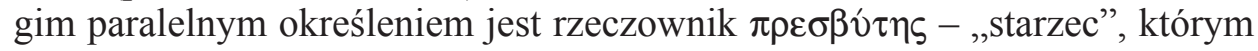

${ }^{38}$ Por. G.M. Baran, Życie i śmierć Antiocha IV Epifanesa w przekazach pozabiblijnych i biblijnych. Historia i teologia, Tarnów 2015, 24.

${ }^{39}$ Por. Gregorius Nazianzenus, Oratio XV 11, PG 35, 932.

${ }^{40}$ Św. Grzegorz (Oratio XV 11, PG 35, 932) w tym kontekście wspomniał także niejakiego Szymona, od którego rozpoczęły się wszelkie niepokoje wokół świątyni za arcykapłana Oniasza III (por. 2Mch 3, 3). Autor 2Mch podał jego pochodzenie: ,z rodziny Bilgi” (2Mch 3, 4), natomiast w 4Mch pominięty jest ten szczegół (por. 4Mch 4,1). Nazjanzeńczyk również pominął ten szczegół, co może sugerować, że dane historyczne jednak czerpał z 4Mch. Jednakże nie stanowi to podstawy do ostatecznego rozstrzygnięcia.

${ }^{41}$ Por. Gregorius Nazianzenus, Oratio XV 3, PG 35, 913; XV 10, PG 35, 929; XV 12, PG 35, 932.

${ }^{42}$ Por. tamże XV 3, PG 35, 913; XV 6, PG 35, 921. 
został określony wiek Eleazara ${ }^{43}$. Autor 2 Mch co prawda również zaznaczył, że Eleazar był posuniętym w latach mężem (por. 2Mch 6,18), który ma dziewięćdziesiąt lat (por. 2Mch 6,24), ale nie użył wspomnianego określenia. Św. Grzegorz przedstawił nadto Eleazara jako ojca siedmiu braci męczenników ${ }^{44}$. Trudno orzec, czy Nazjanzeńczyk miał na uwadze faktyczne ojcostwo, czy też duchowe ${ }^{45}$. Ze wzmianki: „Wprzód ojciec ( $\left.\pi \alpha \tau \eta ́ \eta\right)$ się potykał, walczyć będą i synowie $(\pi \alpha \hat{\imath} \delta \varepsilon \varsigma)^{\text {"46 }}$, można wnioskować, że św. Grzegorz sugeruje ojcostwo fizyczne. Podobny wniosek może się nasunąć w kontekście apostrofy wyrażonej przez matkę braci machabejskich: „Eleazarze, ojcze nasz

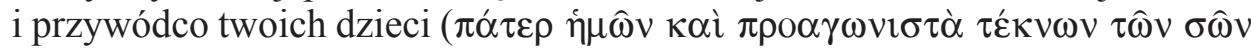

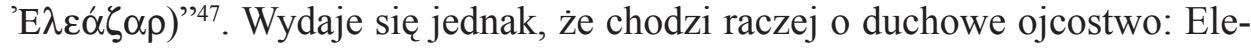
azar - o czym mowa będzie niżej - w przekazie Nazjanzeńczyka jawi się również jako nauczyciel i przewodnik siedmiu braci męczenników. Stąd też określenie go ojcem może stanowić metonimiczne odniesienie do jego funkcji nauczycielskiej. Zgadzałoby się to z tradycją grecką oraz żydowską, w których relacje pomiędzy nauczycielem a uczniem postrzegano jako więzi ojca z synem ${ }^{48}$. Motywu ojcostwa Eleazara - jakkolwiek rozumianego - nie ma

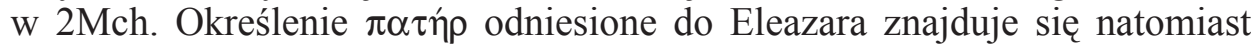
w 4Mch 7, 1. 5. 9. Z pewnością - jak zostało wyżej zaznaczone - chodzi tutaj o odniesienie do jego funkcji nauczyciela (por. 4Mch 9, 6) ${ }^{49}$, gdyż naturalny ojciec męczenników jest wzmiankowany w 4Mch 18, 9, a sam Eleazar jest nazywany nauczycielem/wychowawcą (por. 4Mch 9, 6). W tym kontekście można dostrzec niewątpliwą paralele pomiędzy 4Mch a Oratio XV.

U św. Grzegorza pojawia się także obraz Eleazara jako przewodnika siedmiu braci machabejskich, który względem nich wypełnił posługę wychowawczą $-\pi \alpha 1 \delta \varepsilon i \alpha^{50}$. Wzmiankę na temat wychowawczej roli Eleazara można znaleźć w 2Mch: hagiograf podał, że Eleazar był uczonym w Prawie (por. 2Mch 6, 18: $\gamma \rho \alpha \mu \mu \alpha \tau \varepsilon v ́ \varsigma)$, który z pewnością nauczał tego Prawa. W chwili męczeństwa - według relacji 2Mch - Eleazar stał się przykładem m.in. dla młodzieży (por. 2Mch 6, 28. 31: vं ó $\delta \varepsilon \imath \gamma \mu \alpha)$. Jednakże pod względem słownictwa wzmianka św. Grzegorza odpowiada bardziej przesłaniu 4Mch, w której - w wypowiedzi

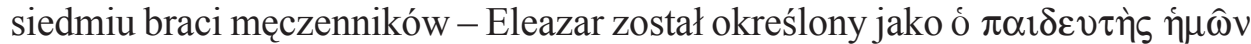

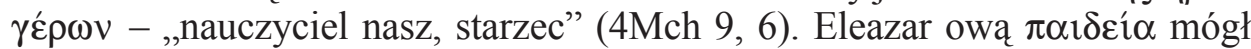
realizować zarówno jako znawca Prawa (por. 4Mch 5, 4: vołıкós) oraz filo-

${ }^{43}$ Por. tamże XV 3, PG 35, 913; 4Mch 5, 6; 7, 10.

${ }^{44}$ Por. Gregorius Nazianzenus, Oratio XV 3, PG 35, 913; XV 6, PG 35, 921.

${ }^{45}$ Por. tamże XV 12, PG 35, 932, gdzie jest wzmianka o duchowym ojcostwie Eleazara, w któ-

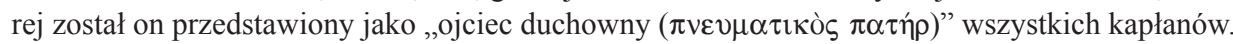

${ }^{46}$ Tamże XV 6, PG 35, 921, tłum. Grużewski, s. 318.

${ }^{47}$ Tamże XV 9, PG 35, 925, tłum. Grużewski, s. 319.

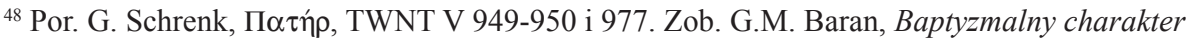
„powtórnego narodzenia” w Tradycji Janowej, Lublin 2008 (mps, Archiwum KUL), 52-53.

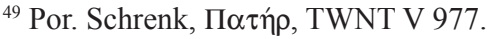

${ }^{50}$ Por. Gregorius Nazianzenus, Oratio XV 3, PG 35, 913. 


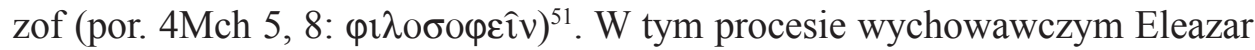
- jak zaznaczył również autor 4Mch - stał się przewodnikiem przede wszystkim przez przykład (por. 4Mch 6, 17-22; 9, 6; 16, 15-17). Bardzo ciekawie tę myśl wyraził św. Grzegorz w wypowiedzi włożonej w usta braci męczenników:

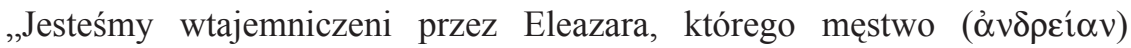
znasz. Wprzód ojciec się potykał ( $\pi \rho \circ \eta \gamma \omega v i ́ \sigma \alpha \tau o)$, walczyć będą i synowie

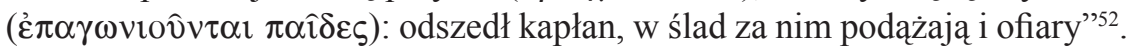

Eleazar jako nauczyciel a także jako kapłan przewodził ( $\pi \rho \circ \sigma \alpha ́ \gamma \omega v)$ siedmiu braciom męczennikom w ich męczeństwie, postrzeganym przez św. Grzegorza zarówno jako zawody, jak i ofiara ${ }^{53}$. Ponadto w tym kontekście Eleazar jawi się w Oratio XV jako „milcząca zachęta $(\sigma \iota \omega \pi \hat{\omega} \sigma \alpha \pi \alpha \rho \alpha i v \varepsilon \sigma \iota \varsigma){ }^{\text {"54 }}$. Podobny motyw poprzedzenia w męczeństwie pojawia się w 4Mch 17, 13, gdzie również jest mowa, że Eleazar jako pierwszy przystąpił do męczeńskiego boju

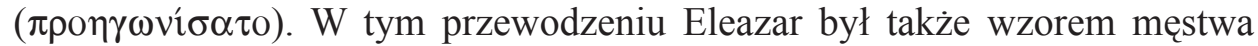
( $\alpha v \delta \rho \varepsilon i \alpha)$ dla braci machabejskich, co podkreślają obaj autorzy ${ }^{55}$.

b) Bracia męczennicy. Pewne zbieżności pomiędzy 4Mch a Oratio XV można dostrzec także w przypadku siedmiu braci męczenników. Podobnie jak autor 4Mch, również i św. Grzegorz zwrócił uwagę na symbolikę liczby siedem. Tego motywu brak w $2 \mathrm{Mch}$. Autor 4Mch interpretując symbolikę siódemki jako liczby braci, w pochwalnej apostrofie zauważył:

„O prześwięta zgodna braci siódemko! Jako bowiem siedem dni stworzenia świata wokół pobożności, tak wokół siódemki w chórze krążąc, strach przed mękami unicestwili”" (4Mch 14, 7-8; por. 13, 7).

U św. Grzegorza występuje swego rodzaju parafraza przytoczonego tutaj cytatu:

„gorliwi szermierze prawdy, wyżsi ponad doczesne rachuby Antiocha, rzetelni uczniowie Prawa Mojżeszowego, dokładni stróże praw ojczystych, stanowiący liczbę czczoną przez Hebrajczyków jako tajemnicę odpocznienia dnia siódmego, jednym żyją, jeden cel sobie stawiają" ${ }^{\text {. }}$.

W obu przypadkach pojawia się odniesienie do motywu stworzenia oraz doskonałej jedności braci, którą wyraża owa siódemka, symbolizująca w Biblii

${ }^{51} \mathrm{~W}$ 4Mch judaizm jest postrzegany jako żydowska filozofia, por. Wojciechowski, Apokryfy z Biblii greckiej, s. 124 i 149.

${ }^{52}$ Gregorius Nazianzenus, Oratio XV 6, PG 35, 921, thum. Grużewski, s. 318.

${ }^{53}$ Por. tamże XV 3, PG 35, 913; XV 6, PG 35, 921.

${ }^{54}$ Tamże XV 3, PG 35, 913, thum. Grużewski, s. 315-316.

${ }^{55}$ Por. tamże XV 6, PG 35, 921; zob. 4Mch 5, 23. Na uwagę w tym kontekście zasługuje fakt, że

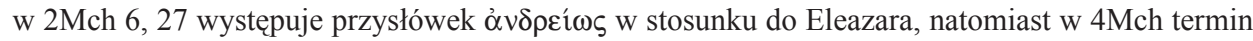
$\grave{\alpha} v \delta \rho \varepsilon i \alpha$ tak jak u św. Grzegorza. Termin $\alpha v \delta \rho \varepsilon i ́ \alpha$ nie pojawia się w 2Mch.

${ }^{56}$ Gregorius Nazianzenus, Oratio XV 3, PG 35, 916, tłum. Grużewski, s. 316; por. tamże XV 6, PG 35, 921. 
doskonałość i pełnię $e^{57}$ U św. Grzegorza w kontekście wzmianki o liczbie siedem występuje nadto litania rozmaitych, godnych pochwały, postaw braci męczenników. Pewną zbieżnością myśli z 4Mch może być wzmianka zawarta w 4Mch 13, 7: ,siedmiowieżowy rozsądek młodzieńców pobożności port umocniwszy, namiętności zwyciężył rozpasane".

Analizując treść omawianych dzieł, można zauważyć także te same określenia zastosowane wobec braci męczenników. Pierwszorzędnie należy zaznaczyć, że często w Oratio XV bracia męczennicy są określani mianem $\pi \alpha \hat{\imath} \delta \varepsilon \varsigma$ - „dzieci, synowie" 58 . Termin ten w 2Mch pojawia się tylko raz (por. 2Mch 7,34 ) w mowie siódmego brata, który wzywa Antiocha IV, aby nie podnosił

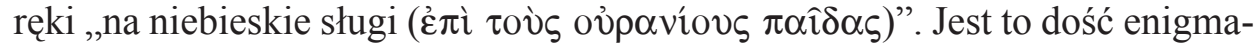
tyczne sformułowanie, które może oznaczać „,dzieci Boga" ${ }^{59}$; w konsekwencji można je odnieść do braci machabejskich. W przeciwieństwie natomiast do 2Mch autor 4Mch dość często używa określania $\pi \alpha \hat{\imath} \delta \varepsilon \varsigma$ względem siedmiu braci (np. 4Mch 9, 18; 15, 6; 16, 1. 6. 8. 9. 15-16; 17, 2-3. 5. 9. 13; 18, 6. 20).

Podobieństwo pomiędzy 4Mch a Oratio XV w przypadku siedmiu braci widać także w używaniu przez obu autorów tych samych epitetów odnoszo-

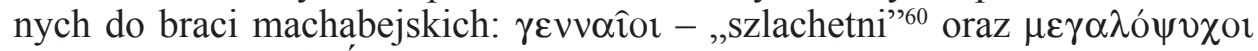
- „wielkoduszni” ${ }^{61}$. Św. Grzegorz określił ich także mianem „,szlachetnej la-

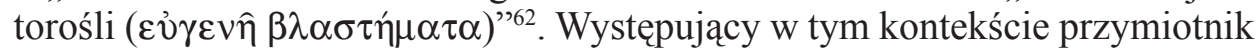

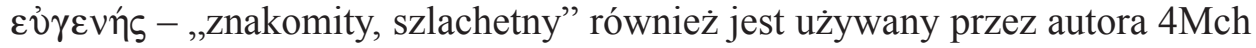
w odniesieniu do braci męczenników (por. 4Mch 9, 13; 10,3).

Prezentując siedmiu braci męczenników, zarówno autor 4Mch, jak i św. Grzegorz wyakcentował ich braterską więź i jedność. Należy podkreślić, że w obu dziełach jest to często pojawiający się motyw, który przewija się w opisie męczeństwa braci machabejskich oraz w przypisywanych im mowach. Autor 4Mch już we wstępnej części swego opisu podał, że wokół matki siedmiu braci jawiło się jako chór (por. 4Mch 8,$4 ; 13,8$ ), który „razem jednym głosem to samo, jakby z jednej piersi" (4Mch 8,29$)$ odpowiadał Antiochowi IV na wszelkie namowy do złamania Prawa. W 4Mch 13, 19 - 14, 10 autor zawarł głębszą refleksję na temat jedności i miłości braterskiej, podając, że „braterstwa czar" udzieliła siedmiu braciom boska i przemądra opatrzność. Ta braterska miłość jako wyraz jedności braci była wynikiem nie tylko spłodzenia ich

${ }^{57}$ Por. L. Ryken - J.C. Wilhoit, Stownik symboliki biblijnej. Obrazy, symbole, motywy, metafory, figury stylistyczne i gatunki literackie w Piśmie Świętym, tłum. Z. Kościuk, Prymasowska Seria Biblijna, Warszawa 1998, 904-905.

${ }^{58}$ Por. np. Gregorius Nazianzenus, Oratio XV 3, PG 35, 923; XV 4, PG 35, 916; XV 5, PG 35, 917; XV 6, PG 35, 921; XV 8, PG 35, 925; XV 9, PG 35, 928; XV 10, PG 35, 929; XV 12, PG 35, 932.

${ }^{59}$ Por. R. Doran, 2 Maccabees. A Critical Commentary, Hermeneia - A Critical and Historical Commentary on the Bible, Minneapolis 2012, 162.

${ }^{60}$ Por. Gregorius Nazianzenus, Oratio XV 3, PG 35, 913; XV 5, PG 35, 917; zob. 4Mch 8, 3; $17,24$.

${ }^{61}$ Por. Gregorius Nazianzenus, Oratio XV 3, PG 35, 913-916; zob. 4Mch 15, 10.

${ }^{62}$ Gregorius Nazianzenus, Oratio XV 3, PG 35, 916, thum. Grużewski, s. 316. 
przez jednego ojca oraz narodzenia się $\mathrm{z}$ tego samego łona matczynego (por. 4Mch 13, 19; 10, 2), ale także wzajemnego dorastania, wspólnego kształtowania się, a nade wszystko ćwiczenie się w Bożym Prawie (por. 4Mch 13, 20-24). Nabycie dzięki Prawu tych samych cnót - jak zauważył autor 4Mch - umocniło ,ich wzajemną przychylność i zgodę" (4Mch 13, 25). Ta wzajemna miłość braterska - jak wynika z przekazu 4Mch - pomogła wytrwać braciom w czasie tortur, ponoszonych $\mathrm{w}$ imię wierności nakazom Prawa ${ }^{63}$. W poetycki sposób autor 4Mch tak opisał tę braterską miłość:

„O święta i harmonijna zgodo siedmiu braci co do pobożności! Żaden z siedmiu młodzieniaszków nie stchórzył ani wobec śmierci się nie zawahał [...]. O prześwięta zgodna siódemko! [...] wokół siódemki w chórze krążąc, strach przed mękami unicestwili" (4Mch 14, 3-4. 7. 8).

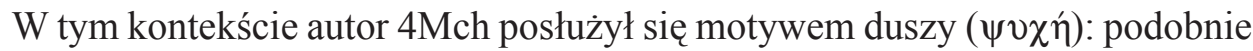
jak dusza swymi impulsami porusza członki ciała ${ }^{64}$, tak jedna dusza pobudzała siedmiu braci w ich walce o zachowanie wierności Prawu (por. 4Mch 14, 6).

Jednym z przejawów tej jedności w miłości braterskiej były wzajemne zachęcania się do wytrwania na torturach, aby tylko zachować wierność Prawu (por. 4Mch 9, 23; 13, 9-18). Wytrwałość i poniesienie męczeństwa dla Prawa kolejni bracia poczytywali sobie jako wyraz trwania w jedności braterskiej (por. 4Mch 10, 3; 11, 22; 12, 16).

W bardzo podobny sposób podejmuje kwestię braterskiej więzi św. Grzegorz. Podkreślił zatem, że są braćmi, którzy „pochodzą z jednego łona

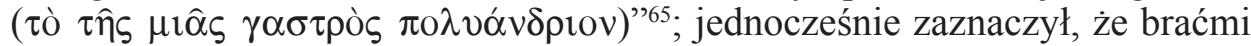

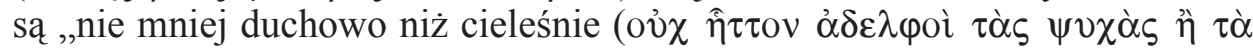
$\sigma \omega \mu \alpha \tau \alpha)^{" 66}$. Ważnym elementem budowania tej braterskiej jedności było wychowanie młodzieńców w Prawie, co zaowocowało ich gorliwością w obronie zachowania nakazów tegoż Prawa. Stąd też wyrazem tej jedności braterskiej dla Nazjanzeńczyka było wspólne pragnienie śmierci męczeńskiej, która miała być świadectwem ich wierności Prawu, a co za tym idzie zwycięstwa nad prześladowcami. W tym kontekście św. Grzegorz posłużył się - podobnie jak autor 4Mch - symboliką liczby siedem:

„A ty przeciwko Prawu Boga stajesz do boju, [...] przeciwko siedmiu bra-

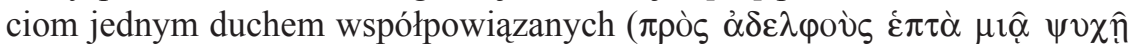
$\sigma v v \delta \varepsilon \delta \varepsilon \mu \varepsilon \dot{\varepsilon} v 0)_{\text {) }}$, przeciwko siedmiu symbolom zwycięstwa" ${ }^{\circ 7}$.

Do tego motywu komplementarnym określeniem jest stwierdzenie:

\footnotetext{
${ }^{63}$ Por. Wojciechowski, Apokryfy z Biblii greckiej, s. 179.

${ }^{64}$ Takie postrzeganie funkcji duszy jest typowo greckie, a w szczególny sposób charakterystyczne dla stoicyzmu, por. tamże, s. 182.

${ }^{65}$ Gregorius Nazianzenus, Oratio XV 7, PG 35, 924, thum. Grużewski, s. 319.

${ }^{66}$ Tamże XV 3, PG 35, 916, thum. Grużewski, s. 316.

${ }^{67}$ Tamże XV 6, PG 35, 921, thum. Grużewski, s. 318.
} 
„[prześladowcy] bardzo wielkiej doznali klęski od zjednoczonych duchowo ( $\sigma v \mu \psi v \chi i \alpha \varsigma)$ siedmiu braci walczących w obronie swojej wiary" ${ }^{98}$.

Podobnie jak w 4Mch, pojawia się w Oratio XV motyw wzajemnych zachęt braci, aby wytrwali w czasie próby i odnieśli zwycięstwo ${ }^{69}$. W tym kontekście Nazjanzeńczyk wykorzystał motyw z Ps 132, 1, wkładając w usta braci następujące stwierdzenie:

„Pięknie jest braciom współmieszkać, współucztować społem, lecz piękniejszą jest rzeczą wspólne narażanie się dla cnoty" ${ }^{\prime 70}$.

Duchowa, a nie tylko cielesna więź braci, bardzo wymownie została wyrażona przez św. Grzegorza w kolejnej zachęcie wypowiedzianej przez braci męczenników:

„Okażmy się braćmi jedni drugich zarówno przez urodzenie, jak i przez śmierć, a walczmy wszyscy jak jeden mąż i każdy za wszystkich"’’1.

W swych rozważaniach Nazjanzeńczyk poszedł dalej, gdyż podał, że bra-

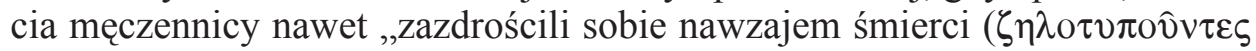
$\dot{\alpha} \lambda \lambda \hat{\eta} \lambda$ ov $\tau \hat{\eta} \varsigma \tau \varepsilon \lambda \varepsilon v \tau \hat{\eta} \varsigma$ )" 72 . Jedyną zaś ich obawą było to, „by tyran nie zaprzestał zadawania męczarni $\mathrm{i}$ w ten sposób niektórzy $\mathrm{z}$ nich nie odeszli bez wieńca zwycięstwa i by wbrew swej woli nie zostali rozdzieleni oraz nie odnieśli złego zwycięstwa, narażając się na nieodbycie męczeństwa"73.

Na zakończenie prezentacji siedmiu braci, jakiej dokonał św. Grzegorz, należy jeszcze zauważyć, że Nazjanzeńczyk zwrócił uwage - podobnie jak autor $4 \mathrm{Mch}$ - na fakt uświęcenia się męczenników ${ }^{74}$. To uświęcenie, które - według przekazu 4Mch 17, 20 - sprawił sam Bóg, mogło się dokonać dzięki wierności Prawu, jaką wykazali młodzieńcy. Św. Grzegorz podał odnośnie tej kwestii następujący argument:

„Tak dokonali ofiary młodości synowie nie służąc rozkoszy, lecz panując nad cierpieniami ( $\tau \hat{\omega} v \pi \alpha \theta \hat{\omega} v$ - czyli namiętnościami) i uświęcając własne ciała"75.

${ }^{68}$ Tamże XV 8, PG 35, 925, thum. Grużewski, s. 319. Należy zauważyć, że zewnętrznym wyrazem jedności braci w zmaganiach o zachowanie wierności Prawu w przekazie Nazjanzeńczyka były gesty wzajemnego obejmowania się i ściskania się braci, por. tamże XV 7, PG 35, 924. Ponadto o czym będzie jeszcze dalej mowa - św. Grzegorz przyrównuje braci męczenników w ich zmaganiach do szyku bojowego, co stanowi metaforyczne podkreślenie ich wspólnego, zjednoczonego działania.

${ }^{69}$ Por. tamże XV 7, PG 35, 924.

${ }^{70}$ Tamże XV 7, PG 35, 924, thum. Grużewski, s. 318.

${ }^{71}$ Tamże, thum. Grużewski, s. 319.

${ }^{72}$ Tamże XV 3, PG 35, 916, thum. Grużewski, s. 316. W kontekście przywołanego cytatu poja-

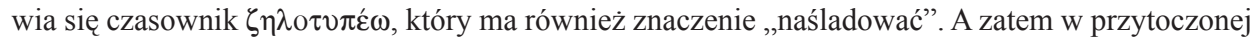
frazie można dopatrywać się motywu wzajemnego naśladowania braci w kwestii śmierci męczeńskiej, co jest obecne w 4Mch.

${ }^{73}$ Tamże.

${ }^{74}$ Por. 4Mch 17,19-20. Zob. Gregorius Nazianzenus, Oratio XV 10, PG 35, 929.

${ }^{75}$ Gregorius Nazianzenus, Oratio XV 10, PG 35, 929, tłum. Grużewski, s. 321. 
Taka argumentacja wpisuje się oczywiście w tok rozważań 4Mch, gdzie odnośnie siedmiu braci pojawia się następujące stwierdzenie: „Jeśli tedy aż do śmierci cierpieniami siedmiu braci wzgardziło, trzeba się zgodzić pod każdym względem, że pobożny rozum jest samowładcą namiętności” $(4 \mathrm{Mch} 13,1)^{76}$.

c) Matka siedmiu braci. Wiele paraleli można dostrzec również w przypadku prezentacji matki braci machabejskich. Na pierwsze miejsce wysuwa się określenie jej jako „szlachetna matka ( $\gamma \varepsilon v \nu \alpha i \alpha \mu \eta \dot{\tau} \tau \eta \rho){ }^{\prime \prime 77}$. Sw. Grzegorz kilkakroć podkreślił fakt, że owa matka w chwili męczeństwa swych dzieci była już starszą kobieta, o czym świadczy wzmianka o jej siwych włosach ${ }^{78}$, starości ${ }^{79}$ oraz starczym ciele ${ }^{80}$. Podobnie scharakteryzował ją autor $4 \mathrm{Mch}$, który określił ją jako „starą matkę ( $\gamma \varepsilon \rho \alpha i \grave{\alpha} \mu \eta \dot{\tau} \tau \rho)$ ” (4Mch 8, 3) i w kilku miejscach wyakcentował jej starość (por. 4Mch 8, 20;16, 1; 17,9).

Wspólnym motywem Oratio XV oraz 4Mch jest „osobliwa miłość” matki względem swych dzieci - „wbrew naturalnemu porządkowi" ${ }^{\circ 1}$. Autor 4Mch dość szeroko omawia to zagadnienie (por. 4Mch 14, 11 - 17, 6), które streszcza się w następującym stwierdzeniu:

„Matka dwie [możliwości] mając przed sobą, pobożność i dla siedmiu synów doraźny ratunek wedle tyrana obietnic, raczej pobożność umiłowała, dając ratunek dla życia wiecznego wedle Boga" (4Mch 15, 2-3).

Matka siedmiu synów, zamiast lamentować nad niedolą dzieci, zamiast ich namówić - zgodnie z oczekiwaniami prześladowców - aby złamali Prawo, a przez to ocalili życie, zachęcała ich do wierności Prawu nawet za cenę ofiary z życia (por. 4Mch 15, 12; 16, 15-25). Autor 4Mch z emfazą stwierdził, że „z powodu bojaźni Bożej zlekceważyła doraźny ratunek dla dzieci” (4Mch 15, 8), mając na uwadze nagrodę wieczną za ich zwycięstwo w ,świętych zawodach". W celu uwypuklenia heroicznej miłości matki autor 4Mch zestawia ją z innymi kobietami, zauważając, że ,im bardziej [...] słabego ducha i wielodzietne są matki, tym bardziej dzieci kochają" (4Mch 15, 5) i w konsekwencji chcą ocalić je od doczesnych nieszczęść. Aby wzmocnić swą argumentację, autor 4Mch odwołał się do przykładu zwierząt, które dla ocalenia życia swego potomstwa podejmują wszelkie możliwe sposoby ratunku (por. 4Mch 14, 1319). Matka braci machabejskich potrafiła jednak zapanować nad naturalnymi

${ }^{76}$ Wyakcentowanie przez św. Grzegorza faktu, że męczennicy jako młodzieńcy panowali nad rozkoszami/namiętnościami, może być nawiązaniem do rozważań autora 4Mch, który pouczając o wstrzemięźliwości, odwołał się do przykładu Józefa Egipskiego: „Dlatego właśnie wstrzemięźliwy Józef jest wychwalany, ponieważ myślą opanował pociag do przyjemności. Młodym bowiem będąc i u szczytu potencji, poskromił rozumem namiętną żądzę" (4Mch 2, 2-3).

${ }^{77}$ Por. Gregorius Nazianzenus, Oratio XV 4, PG 35, 916, thum. Grużewski, s. 316; XV 8, PG 35, 925; XV 12, PG 35, 932; XV 5, PG 35, 917 (przymiotnik w stopniu wyższym). Zob. 4Mch 15, 24.

${ }^{78}$ Por. Gregorius Nazianzenus, Oratio XV 4, PG 35, 916; XV 8, PG 35, 925.

${ }^{79}$ Por. tamże XV 4, PG 35, 917; XV 9, PG 35, 928.

${ }^{80}$ Por. tamże XV 9, PG 35, 929.

${ }^{81}$ Por. tamże XV 4, PG 35, 916. 
odruchami macierzyńskiej miłości (por. 4Mch 14,11), a przez to poświadczyła swą prawdziwą miłość matczyną, ukierunkowaną na wieczne szczęście swych dzieci (por. 4Mch 17, 5). Ważnym elementem prezentacji matki w 4Mch jest ukazanie jej jako kobiety, która panuje nad typowymi - jak zaznaczył autor 4Mch - emocjami matek (por. 4Mch 16, 3), będącymi zgodnie z naturą bardziej współczującymi dla swych dzieci niż nawet ojcowie (por. 4Mch 15, 4). Stąd też - jak podkreślił autor 4Mch - matka nie lamentowała, ani nie rozpaczała, co więcej - ani nie uroniła łzy, widząc okrutne męki i śmierć swych dzieci (por. 4Mch 15, 19-20; 16, 12).

Tak samo przedstawił matkę siedmiu braci św. Grzegorz, który stwierdził:

„Nie litowała się bowiem nad dziećmi, lecz konała w obawie, aby nie ominęło ich męczeństwo" "82.

„A szlachetna matka, będąc nią rzeczywiście w stosunku do nich - tak licznych i tak cnotliwych - jako wielka i wielkoduszna wyznawczyni Prawa Mojżeszowego - w tym czasie doznała radości i obawy zarazem pozostając pomiędzy tymi dwoma uczuciami: radości, z powodu oglądania męstwa; obawy, z powodu niepewności tego, co miało nastapić, i wzmagania się zadawanych synom udręczeń" $"$.

Ponadto Nazjanzeńczyk bardzo mocno również wyakcentował brak rozpaczy, czy też lamentacji ze strony matki, która patrzyła na męczarnie swych dziecis ${ }^{84}$. Jak zaznaczył, prawdziwy powód do opłakiwania dzieci matka miałaby wówczas, gdyby synowie nie wytrwali i pod wpływem namów, gróźb prześladowców, czy też samych tortur okazali się niewierni Prawu ${ }^{85}$.

Mówiąc o mężnym znoszeniu przez matkę widoku męczonych dzieci, obaj autorzy podkreślili, że źródłem tego było jej zaufanie, czy też oddanie się $\mathrm{Bogu}^{86}$. Wspólnym motywem analizowanych dzieł jest interpretacja ofiary matki siedmiu synów jako ofiary Abrahama $\mathrm{z}$ Izaaka ${ }^{87}$, którą ofiara matki machabejskiej nawet - zdaniem św. Grzegorza - przewyższyła ${ }^{88}$. Ofiara matki - jak zauważyli obaj autorzy - miała również wymiar duchowy ${ }^{89}$.

Bardzo wyraźnym punktem stycznym w przypadku prezentacji osoby matki w 4Mch oraz Oratio XV jest opis okoliczności jej śmierci. Autor 4Mch podał następujący opis:

„Mówili zaś niektórzy z włóczników, że gdy miała być zabrana i ona na śmierć, żeby nikt nie chwycił jej ciała, sama rzuciła się w ogień" (4Mch 17, 1).

\footnotetext{
${ }^{82}$ Tamże XV 4, PG 35, 916, thum. Grużewski, s. 316.

${ }^{83}$ Tamże XV 8, PG 35, 925, thum. Grużewski, s. 319.

${ }^{84}$ Por. tamże XV 9, PG 35, 928.

${ }^{85}$ Por. tamże.

${ }^{86}$ Por. tamże XV 9, PG 35, 928. Zob. 4Mch 15, 24.

${ }^{87}$ Por. Gregorius Nazianzenus, Oratio XV 4, PG 35, 916. Zob. 4Mch 14, 20; 15, 28.

${ }^{88}$ Por. Gregorius Nazianzenus, Oratio XV 4, PG 35, 916.

${ }^{89}$ Por. tamże; XV 9, PG 35, 928. Zob. 4Mch 15, 21-23. 29.
} 
Decydując się na tego rodzaju posunięcie, matka machabejska być może nie chciała dopuścić, aby w jakikolwiek sposób oprawcy pohańbili jej ciało ${ }^{90}$. Podobna wzmianka znajduje się w Oratio XV:

„To powiedziała i została dołączona do swoich dzieci. W jaki sposób? Jak biegnąca do komnaty małżeńskiej - na stos [tak bowiem opiewał wyrok] nawet nie czekając na prowadzących ją aby snadź skalane ciało nie tknęło się ciała świętego i szlachetnego" ${ }^{\prime 1}$.

Warto zaznaczyć, że autor 2Mch nie podaje żadnych okoliczności śmierci owej kobiety, ograniczając się jedynie do krótkiego stwierdzenia: „Ostatnia po synach zmarła matka" (2Mch 7,41$)$.

\section{Agonistyczno-militarna metaforyka w opisie męczeństwa (poko-} nanie tyrana, zdobycie cnoty). Jednym z głównych motywów, jaki - w odróżnieniu od $2 \mathrm{Mch}$ - pojawia się w $4 \mathrm{Mch}$, jest motyw agonistyczny. Autor 4Mch nawiązał zatem do metaforyki zawodów sportowych, aby opisać metaforycznie śmierć męczenników machabejskich. Stąd też męczennicy określeni zostali mianem zawodników/sportowców: $\alpha \theta \lambda \eta \tau \eta \dot{s}$ - ,zapaśnik, szermierz, atleta" (4Mch 6,$10 ; 17,15-16), \grave{\alpha} \gamma \omega v \iota \sigma \tau \eta ́ s-$, ,zapaśnik, wojownik, bojownik, zawodnik, szermierz" (4Mch 12,14); a zniesione mężnie tortury zwieńczone

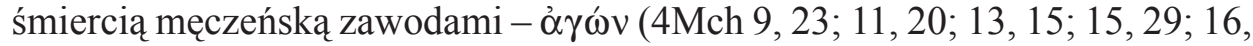
$16 ; 17,11)$. Te szczególne zawody zostały przez autora $4 \mathrm{Mch}$ określone roz-

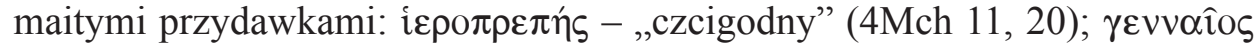
- „szlachetny, dobry, wzniosły” (4Mch 16, 16); சcîo - „boski” (4Mch 17, 11). Również inne określenia, jakimi posłużył się autor 4Mch, nawiązują do metaforyki sportowej. Przykładem jest słowo $\hat{\alpha} \theta \lambda o v$, które stanowi fachowy termin określający „nagrodę za zwycięstwo w zawodach” (4Mch 9, 8), czy też przyrównanie męczenników do biegaczy na drodze ku nieśmiertelności (por.

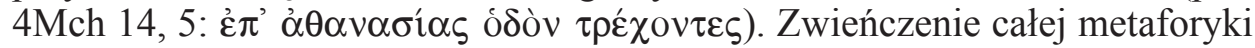
agonistycznej znajduje się natomiast w tym fragmencie:

„Zaprawdę były to bowiem boskie zawody, w których wystapili. Nagród rozdawczynią cnota, wytrwałość oceniająca; zwycięstwem niezniszczalność w życiu długotrwałym. Eleazar pierwszym zawodnikiem, matka siedmiu chłopców się dołączyła, bracia zaś współzawodniczyli. Tyran był przeciwnikiem; świat i ludzkość widzami; cześć dla Boga zwyciężyła, swoich sportowców uwieńczając. Któż nie zdumiewał się sportowcami boskiego prawodawstwa? Któż się nie przejął" (4Mch 17, 11-16).

Autor 4Mch opisując cały proces męczeństwa, zwrócił także uwagę na istotny element odbywających się zawodów sportowych, czyli na widownię, którą

${ }^{90}$ Por. G.M. Baran, Kobiety w kulturze i religii spoleczności żydowskiej w świetle Ksiag Machabejskich, „Studia Ełckie” 16 (2014) 421.

${ }^{91}$ Gregorius Nazianzenus, Oratio XV 10, PG 35, 929, thum. Grużewski, s. 320. 
stanowił świat i ludzkość. Całość tych zawodów stanowiło zmaganie się o cnotę (por. 4Mch 9, 8; 12, 14; 11, 2), a ostateczną nagrodą było uświęcenie przez Boga męczenników i życie wieczne z Nim (por. 4Mch 10, 15; 16, 13; 17, 17-20; 18, 3. 23). Owocem tych zmagań było również zwycięstwo nad przeciwnikiem, czyli Antiochem IV. Autor 4Mch sugestywnie określił to jako „obalenie/zwyciężenie tyrani/tyrana" (por. 4Mch 1, 11; 8, 2. 15; 9, 30; 11, 24; 17, 2; 18, 5). W kontekście metaforyki agonistycznej na uwagę zasługuje również tytuł, jakim została obdarzona matka siedmiu braci: „,W wewnętrznych zawodach mistrzyni ( $\tau 0 \hat{v}$

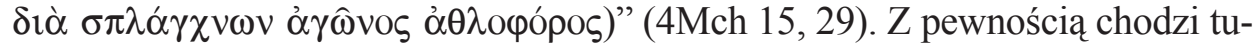
taj o jej wewnętrzne zmagania pomiędzy rozumem a matczynymi uczuciami, co w konsekwencji zaowocowało swego rodzaju duchowym męczeństwem ${ }^{92}$, gdyż musiała jako matka patrzeć na męczeństwo własnych dzieci: chociaż odwodząc je od wierności Prawu, mogła je uratować od śmierci, ona jednak poprzez nieustanne zachęty czuwała niejako, aby wytrwały do końca.

Obok metaforyki agonistycznej - w nieco mniejszym wymiarze - w 4Mch występują metafory militarne. Autor $4 \mathrm{Mch}$ przyrównał męczeństwo również do wyprawy wojennej, w której biorą udział męczennicy. Zostało to wyrażone w apostroficznym wezwaniu pierwszego z braci: „Świętym i szlachetnym

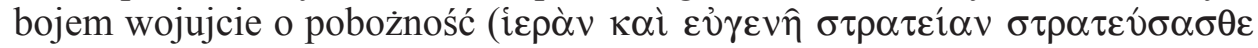

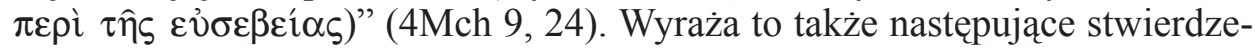
nie autora 4Mch:

„stawszy się szlachetnymi i mężnymi w walce pieszej i w oblężeniu (عiৎ

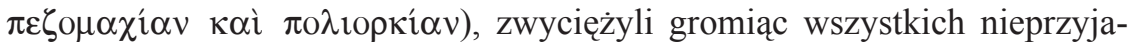
ciół" (4Mch 17, 24).

Stąd też wystapienie męczenników w obronie Prawa autor 4Mch opisał za pomocą czasowników: $\pi \rho \circ \alpha \sigma \pi^{i} \zeta \omega$ - „trzymać tarczę, bronić, osłaniać” (4Mch 6, 21), i $\pi \varepsilon \rho \alpha \sigma \pi i \zeta \omega-$ „osłaniać, zakrywać tarczą" (4Mch 7,8) oraz $\kappa \alpha \theta 0 \pi \lambda i \zeta \omega$ - ,uzbroić, pokonać, zwalczyć” (4Mch 13, 16). W opisie zaś mężnego znoszenia męki przez Eleazara zastosował motyw obleganego miasta:

„Żadne miasto licznymi i rozmaitymi machinami oblegane tak ich nie odparło, jak ów prześwięty [mąż]. Dusza jego święta udrękami i torturami w ogniu trawiona zwyciężyła oblegających za sprawą tarczy strzegącego pobożności rozumu" (4Mch 7, 4).

Szósty z braci natomiast został ukazany jako „szlachetnością uzbrojony

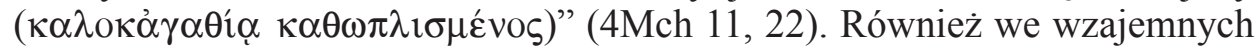
zachętach braci pojawia się wezwanie o charakterze militarnym:

„Uzbrójmy się tedy władzą nad namiętnościami od boskiego rozumu

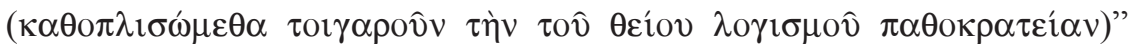
(4Mch 13, 16).

\footnotetext{
${ }^{92}$ Por. Baran, Kobiety w kulturze i religii społeczności żydowskiej, s. 414-418.
} 
Zaś siódmy z braci ewentualne ocalenie życia za cenę przekroczenia nakazów Prawa przyrównuje do dezercji (por. 4Mch 12, 16: $\alpha \pi \alpha v \tau o \mu \circ \lambda \varepsilon \dot{\varepsilon} \omega$ ). Na szczególną uwagę zasługuje bezpośrednie określenie matki braci męczenników jako $\theta \varepsilon o \hat{v} \sigma \tau \rho \alpha \tau \imath \hat{\omega} \tau \iota \varsigma$-,żołnierz Boga” (4Mch 16, 14). Ciekawą kwestią jest również określenie Antiocha IV, który w stosunku do „,walczących” męczen-

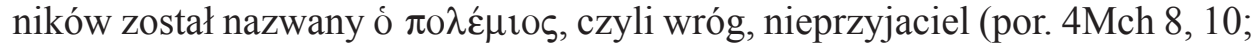
$11,23 ; 17,24)$ o charakterze wojennym ${ }^{93}$. Owocem tej walki było zwycięstwo, wyrażające się - jak zostało wyżej powiedziane - w obaleniu tyrana/tyranii. Jak zaznaczył autor 4Mch, Antioch IV nie osiagnnąwszy zamierzonego celu, opuścił Jerozolimę i podjął wyprawę na Persję (por. 4Mch 18, 5).

Również św. Grzegorz w swej mowie - chociaż w nieco skromniejszym wymiarze - posłużył się podobną metaforyką. Stąd też Eleazara, który jako pierwszy poniósł śmierć męczeńską, nazwał ,prawym początkiem bojów

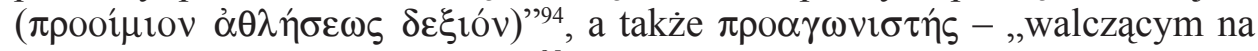
czele, w pierwszych szeregach" 95 , braci zaś męczenników - „,szermierzami prawdy ( $\dot{\alpha} \lambda \eta \theta \varepsilon i \alpha \varsigma \alpha \dot{\alpha} \gamma \omega v i \sigma \tau \alpha i){ }^{\prime \prime 96}$. Ciekawe określenie św. Grzegorz zastosował w stosunku do matki braci machabejskich: zwycięzca olimpijski - 'O $\lambda v \mu \pi \imath$ oví $\eta \varsigma^{97}$. Poniesione tortury oraz śmierć męczeńską Nazjanzeńczyk przyrównał natomiast do zawodów sportowych opisywanych terminami:

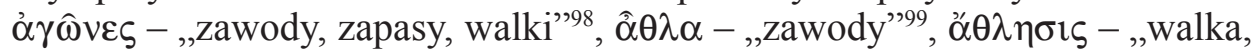
zapasy”"100, czy też $\alpha \gamma \omega \dot{v} v \_\mu \alpha$ - „walka"101. Podjęte zaś dobrowolne męczeństwo w obronie wierności Prawu św. Grzegorz wyraził za pomocą czasow-

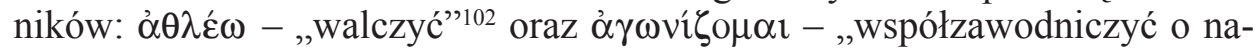
grodę, walczyć, bić się"103; $\pi \rho \circ \alpha \gamma \omega v i \zeta o \mu \alpha \imath$ - „walczyć przedtem, walczyć

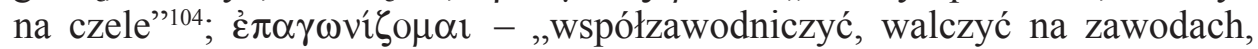
ponownie współzawodniczyć" 105 . Zjednoczonych ze sobą braci męczenników w duchowej walce św. Grzegorz przyrównał natomiast do szyków wojsko-

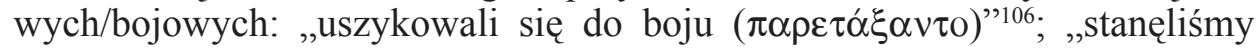

${ }^{93}$ Czasownik $\pi \mathrm{o} \lambda \varepsilon \mu$ í $\zeta \omega$, z którym należy połączyć powyższy termin, posiada znaczenie: ,prowadzić wojnę, wojować".

${ }^{94}$ Gregorius Nazianzenus, Oratio XV 3, PG 35, 913, thum. Grużewski, s. 315.

${ }_{95}$ Por. tamże XV 9, PG 35, 925; XV 6, PG 35, 921.

${ }^{96}$ Tamże XV 3, PG 35, 916, tłum. Grużewski, s. 316.

${ }^{97}$ Tamże XV 9, PG 35, 925, thum. Grużewski, s. 319. Elementem jej zwycięstwa było to, że jej synowie wytrwali aż do śmierci w wierności Prawu.

${ }^{98}$ Por. tamże XV 11, PG 35, 932.

${ }^{99}$ Por. tamże XV 7, PG 35, 924; XV 11, PG 35, 932.

${ }^{100}$ Por. tamże XV 3, PG 35, 913; XV 5, PG 35, 920; XV 11, PG 35, 932; XV 10, PG 35, 929.

${ }^{101}$ Por. tamże XV 9, PG 35, 928.

${ }^{102}$ Por. tamże XV 7, PG 35, 924; XV 9, PG 35, 928; XV 11, PG 35, 932.

${ }^{103}$ Por. tamże XV 8, PG 35, 925; 9, PG 35, 928. 929.

${ }^{104}$ Por. tamże XV 6, PG 35, 921.

${ }^{105}$ Por. tamże.

${ }^{106}$ Tamże XV 5, PG 35, 917, thum. Grużewski, s. 317. 
w szyku bojowym ( $\pi \alpha \rho \alpha \tau \varepsilon \tau \alpha \dot{\gamma} \gamma \mu \varepsilon \theta \alpha)$ i tak żeśmy się uzbroili $(\dot{\omega} \pi \lambda i ́ \sigma \mu \varepsilon \theta \alpha)$ "107;

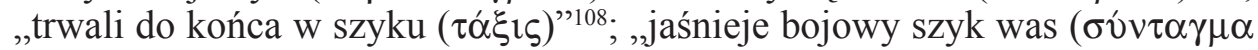
$\hat{v} \mu \hat{\omega} v)$ "'109. Podobnie jak w 4Mch całość zmagań męczenników Nazjanzeńczyk

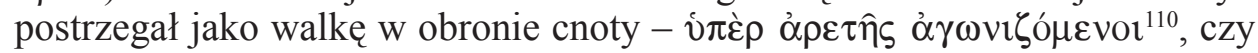

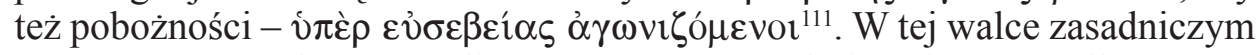
orężem męczenników - według św. Grzegorza - była pobożność, dlatego zo-

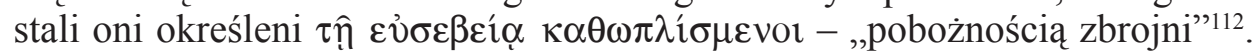
Natomiast obwarowaniem w oblężeniu przez wrogów (por. 4Mch 17, 24) było dla nich Prawo ${ }^{113}$. Nazjanzeńczyk zwrócił uwagę również na dość ciekawy aspekt zmagań braci męczenników z Antiochem IV: było nim wygłaszanie mów przez Antiocha IV oraz braci męczenników, którzy poprzez odpowiedni dobór argumentów starali się odpierać zarzuty prześladowcy. W tym kontekście Nazjanzeńczyk użył metafory szyków bojowych: męczennicy uzbrojeni stosownymi argumentami przeciwstawiali się „,Szykowi niebezpieczeństw” ze strony Antiocha IV ${ }^{114}$. Owocem tej walki/zmagania się z Antiochem IV była - podobnie jak w 4Mch - klęska Seleucydy, któremu nie udało się zmusić męczenników do złamania Prawa ${ }^{115}$. Stąd też - jak zaznaczył św. Grzegorz w podobny sposób do autora 4Mch - pokonany Antioch IV „odszedł niczego nie dokonawszy"116. Ostatecznym natomiast owocem podjętych przez męczenników zmagań było - podobnie jak w 4Mch - uświęcenie się męczenników $^{117}$ oraz osiągnięcie życia wiecznego z Bogiem ${ }^{118}$. Nagrodzenie całości zwycięstwa męczenników zarówno autor 4Mch, jak i św. Grzegorz opisał

${ }^{107}$ Tamże XV 5, PG 35, 920, thum. Grużewski, s. 317.

${ }^{108}$ Tamże XV 8, PG 35, 925, tłum. Grużewski, s. 319.

${ }^{109}$ Tamże XV 9, PG 35, 928, tłum. Grużewski, s. 320.

${ }^{110}$ Tamże XV 9, PG 35, 928; por. XV 2, PG, 35, 913; XV 5, PG 35, 920; XV 7, PG 35, 924.

${ }^{111}$ Tamże XV 8, PG 35, 925.

${ }^{112}$ Tamże XV 10, PG 35, 928, thum Grużewski, s. 321. Por. tamże XV 5, PG 35, 920.

${ }^{113}$ Por. tamże XV 5, PG 35, 920.

${ }^{114}$ Por. tamże XV 5, PG 35, 917-920. Należy w tym miejscu zaznaczyć, że w 2Mch również pojawiają się wypowiedzi braci machabejskich, jednakże są one - z wyjątkiem ostatniej - bardzo krótkie (por. 2 Mch 7, 2. 6. 8-9. 11. 14. 16-17. 18-19. 30-38). W 4Mch występują nieco dłuższe wypowiedzi męczenników, które mają niejako charakter riposty na wcześniejsze słowa Antiocha IV (por. 4Mch 9, 1-9. 15. 17-18. 30-32; 10, 10-11. 18-21; 11, 2-8. 12. 20-27; 12, 11-14. 16-19). Wzmianka w Oratio XV o swego rodzaju wymianie zdań braci męczenników z Antiochem (por. Gregorius Nazianzenus, Oratio XV 5, PG 35, 920) pozwala dostrzec większą zbieżność z 4Mch. Wygłaszanie mów przez Antiocha IV oraz męczenników św. Grzegorz postrzegał również jako swe-

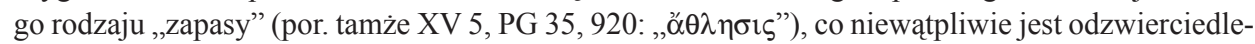
niem starożytnych praktyk związanych z organizowanymi agonami oratorskimi, por. M. Korolko, Sztuka retoryki. Przewodnik encyklopedyczny, Warszawa 1990, 31.

${ }^{115}$ Por. Gregorius Nazianzenus, Oratio XV 6, PG 35, 920-921; XV 10, PG 35, 929.

116 Tamże XV 11, PG 35, 932, tłum. Grużewski, s. 321. Por. 4Mch 18, 5.

${ }^{117}$ Por. Gregorius Nazianzenus, Oratio XV 10, PG 35, 929. Zob. 4Mch 17, 20.

${ }^{118}$ Por. Gregorius Nazianzenus, Oratio XV 5, PG 35, 920; XV 7, PG 35, 924; XV 10, PG 35, 929. 
metaforycznie jako uwieńczenie wieńcem ${ }^{119}$, który był typowym wyróżnieniem dla zwycięscy w starożytnych agonach ${ }^{120}$.

3. Paralelne określenia narzędzi tortur. Analizując zawarty w Oratio XV opis narzędzi tortur, można zauważyć, że św. Grzegorz wymienił dość szerokie ich spektrum, które swoje paralele znajduje przede wszystkim w 4Mch. Dla pewnej przejrzystości zestawimy komplementarnie w tabeli poszczególne nazwy tych narzędzi oraz miejsce ich występowania w omawianych dziełach:

\begin{tabular}{|c|c|}
\hline Oratio XV & 4Mch \\
\hline 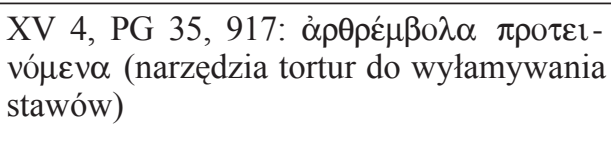 & 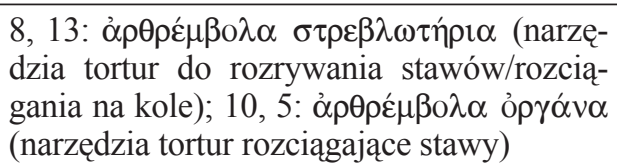 \\
\hline 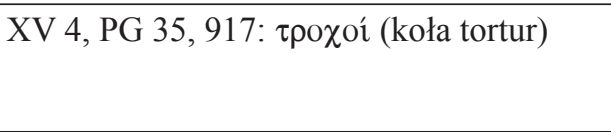 & 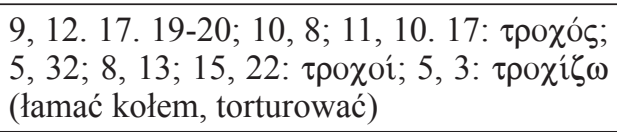 \\
\hline XV 4, PG 35, 917: $\tau \rho о \chi \alpha \nu \tau \hat{p} \rho \varsigma \varsigma$ (skrętacze) & 8, 13: $\tau \rho о \chi \alpha \nu \tau \hat{\eta} \rho \varepsilon \varsigma$ \\
\hline $\begin{array}{l}\text { XV 4, PG 35, 917: } \kappa \alpha \tau \alpha \pi \varepsilon^{\prime} \lambda \tau \alpha \iota \text { (katapulty/ } \\
\text { napinacze) }\end{array}$ & 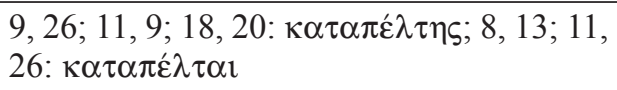 \\
\hline 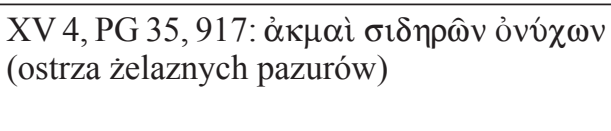 & 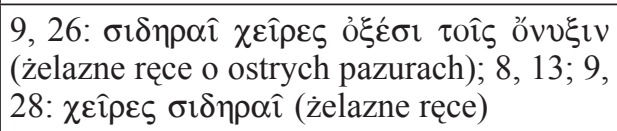 \\
\hline 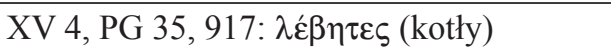 & 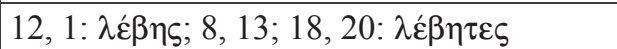 \\
\hline $\begin{array}{l}\text { XV 4, PG 35, 917; XV 6, PG 35, 921: } \pi u ́ \rho \\
\text { (ogień) }\end{array}$ & $\begin{array}{l}5,32 ; 6,24 ; 7,10.12 ; 8,13 ; 9,19.22 ; 10 \text {, } \\
14 ; 11,26 ; 13,5 ; 14,9.10 ; 15,15 ; 18,20: \\
\pi u ́ \rho ; 17,1: \pi v \rho \alpha ́ \text { (stos pogrzebowy, paląca } \\
\text { się masa drzew) }\end{array}$ \\
\hline $\begin{array}{l}\text { XV 6, PG 35, 921: } \delta \varepsilon \sigma \mu \alpha ́ \\
\text { (więzy, kajdany, pęta, okowy) }\end{array}$ & $12,2: \delta \varepsilon \sigma \mu \alpha ́$ \\
\hline 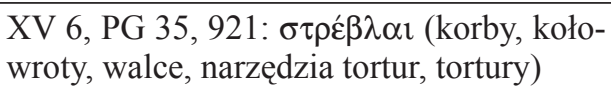 & 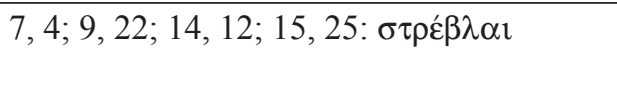 \\
\hline
\end{tabular}

Na uwagę zasługuje fakt, że Nazjanzeńczyk wymienił w swej mowie jako

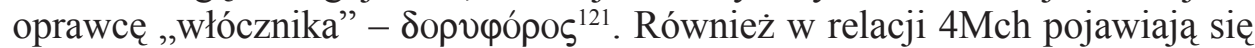
postacie włóczników, którzy brali czynny udział w zadawaniu tortur męczennikom machabejskim (por. 4Mch 5, 2; 6, 1. 8. 23; 8, 13; 9, 16. 26; 11, 9. 27; 17, 1). Warto wspomnieć, że autor $2 \mathrm{Mch}$ w opisie zadawanych tortur męczennikom ani raz nie wzmiankuje włóczników; jedyna wzmianka pojawia się w 2Mch 3 , 24, czyli w całkiem innym kontekście. Pośród narzędzi tortur św. Grzegorz

${ }^{119}$ Por. tamże XV 7, PG 35, 924; XV 9, PG 35, 928. Zob. 4Mch 17, 15.

${ }^{120}$ Por. D. Słapek, Sport i widowiska w świecie antycznym, Kraków - Warszawa 2010, 459-464;

B. Gąssowska, Wieniec, w: Stownik kultury antycznej, red. R. Kulesza, Warszawa 2012, 511.

${ }^{121}$ Por. Gregorius Nazianzenus, Oratio XV 4, PG 35, 917. 


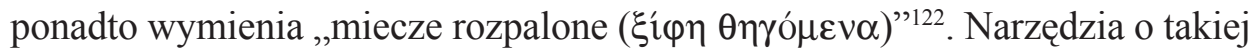
nazwie nie pojawiają się ani w 4Mch, ani w $2 \mathrm{Mch}$. Jedynie luźną paralelę do tego można znaleźć w 4Mch 6, 25, gdzie mowa jest o przypalaniu Eleaza-

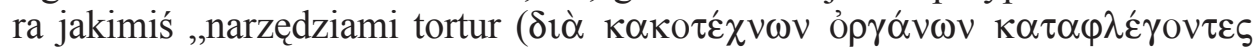

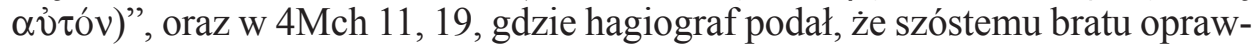

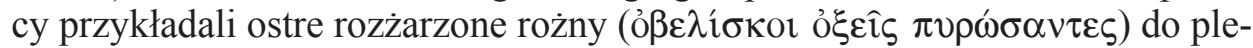
ców, a przebiwszy boki, wypalali mu wnętrzności. Nazjanzeńczyk w kontekście „przypuszczalnej” mowy jednego z braci machabejskich wymienił także

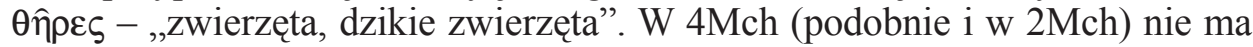
wzmianki na temat dzikich zwierząt, które miałyby stanowić „narzędzie” tortur męczenników. Być może jest to nawiązanie św. Grzegorza do historii Daniela w jaskini lwów, co jest zarówno wzmiankowane w 4Mch, jak i Oratio $\mathrm{XV}^{123}$. W samej 4Mch mamy jedynie metaforyczne określenie oprawców, których autor 4Mch nazwał oi $\pi \alpha \rho \delta \alpha ́ \lambda \varepsilon$ or $\theta \hat{\eta} \rho \varepsilon \varsigma$ - ,dzikie leopardy” (4Mch 9, 28) $)^{124}$.

Mając na uwadze powyższe zestawienie opisów narzędzi tortur, można wysunąc tezę, że św. Grzegorz sięgnął w tym względzie do tekstu 4Mch, w której została opisana znacznie większa ilość tych narzędzi niż w 2Mch, gdzie zostały wymienione jedynie: $\tau \hat{\mu} \mu \pi \alpha v o v$ - „narzędzie tortur, egzekucji” (2Mch 6, 19. 28);

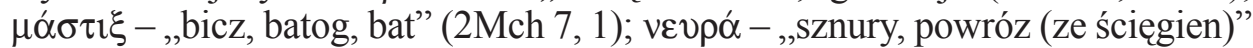

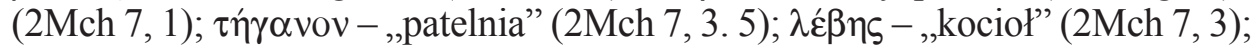
$\pi v \rho \alpha ́$ - „ogien”” (2Mch 7, 5). Jak widać z przytoczonych przykładów, z narzędzi, jakie wymienia św. Grzegorz, w 2Mch występują jedynie „kotły” i „ogień”. Na tym tle wyraźniej widać pewną zależność Oratio XV od 4Mch.

4. Motyw ofiary oczyszczającej naród żydowski. Bardzo interesującym motywem w 4Mch jest niewątpliwie idea oczyszczenia narodu żydowskiego, która dokonała się poprzez ofiarę męczenników. Tę myśl autor 4Mch wyraził w ogólny sposób już w części wstępnej księgi: „oczyszczona została przez

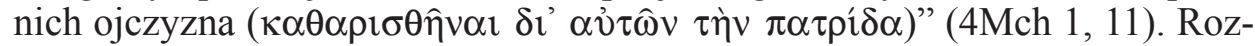
winięcie tej myśli znajduje się w modlitwie Eleazara:

„Litościwy bądź względem swego ludu, niech ci wystarczy nasza zań kaźń. Uczyń mą krew ich oczyszczeniem i jako okup za ich życie zabierz życie

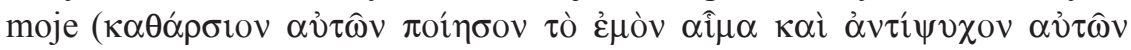

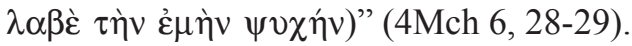

oraz w dalszym komentarzu autora 4Mch:

„ojczyzna [została] oczyszczona, jakby stali się okupem za życie wobec grzechów narodu. A przez krew pobożnych owych i ofiarę przebłagalną ich śmierci

${ }^{122}$ Por. tamże; XV 6, PG 35, 921.

${ }^{123}$ Por. tamże: $\theta \hat{\eta} \rho \varepsilon \varsigma$. Zob. 4Mch 16, 3. 21; 18, 13.

${ }^{124}$ Być może św. Grzegorz wprowadził motyw zwierząt, mając na uwadze męczeństwa pierwszych chrześcijan, którzy ginęli na arenach rozszarpywani przez dzikie zwierzęta, por. np. Tacitus, $A n$ nales 15, 44; Eusebius Caesariensis, HE IV 15, 4; IX 6, 1; tenże, De martyribus Palaestinae 3, 1; 6, 3). 


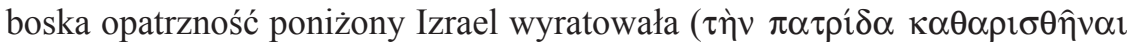

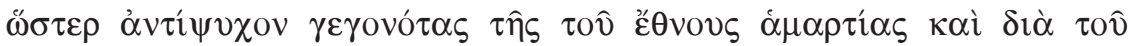

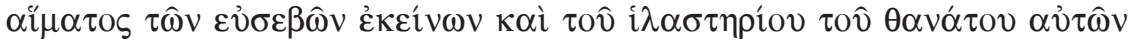

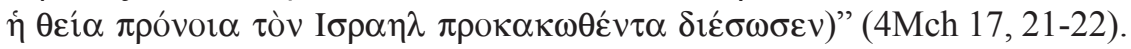
oraz:

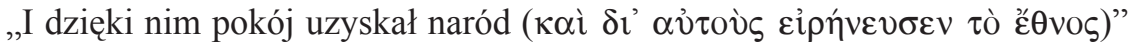
(4Mch 18, 4).

Jak wynika z przytoczonych tekstów, śmierć męczenników - według autora $4 \mathrm{Mch}$ - miała wartość przebłagania za grzechy ludu żydowskiego oraz oczyszczenia ojczyzny ${ }^{125}$.

Podobny motyw pojawia się również w Oratio XV, gdy św. Grzegorz mówi:

„[Eleazar] przedtem składał ofiary i modlił się za lud, teraz jako najdoskonalszą ofiarę oczyszczającą cały lud [...] siebie samego Bogu przywodząc (vôv

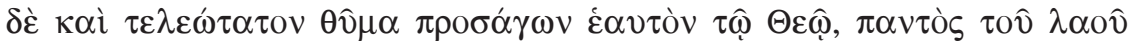
$\kappa \alpha \theta \dot{\alpha} \rho \sigma(0 v) ” " 126$.

W tym kontekście Nazjanzeńczyk przywołał wspomnianą w Rz 12, 1 „ofiarę żywă święta, miłą Bogu" i odniósł ją do złożonej z samego siebie ofiary Eleazara, jednocześnie stwierdzając, że była ona wspanialszą i czystszą niż cała liturgia Starego Przymierza ${ }^{127}$. Do tej myśli św. Grzegorz nawiązał również w dalszej części mowy:

„Tak dokonał ofiary kapłańskiej Eleazar [...], uświęciwszy Izrael nie przez zewnętrzne ablucje, lecz krwią własną i uczyniwszy śmierć ostateczną ta-

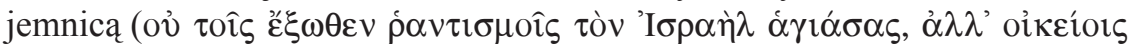

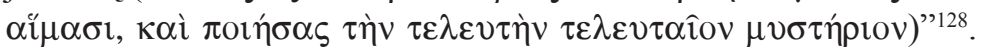

Trudno orzec, w jakim sensie śmierć Eleazara stanowiła „tajemnicę”, ale zawarte na początku mowy ${ }^{129}$ rozważania św. Grzegorza na temat odniesienia męczeństwa męczenników machabejskich do Krzyża Chrystusa pozwalają przypuszczać, że Nazjanzeńczyk widział w śmierci Eleazara tajemniczy związek z ofiarą Krzyża, która miała najdoskonalszy i najpełniejszy wymiar oczyszczenia ludzkości z nieprawości ${ }^{130}$.

Odnosząc się natomiast do męczeństwa braci machabejskich, św. Grzegorz określił ich śmierć jako „ofiarę z ciała”: „nasze ciało złóżmy w ofierze

${ }^{125}$ Por. Wojciechowski, Apokryfy z Biblii greckiej, s. 111; De Silva, 4 Maccabees, s. 137-141.

${ }^{126}$ Gregorius Nazianzenus, Oratio XV 3, PG 35, 913, tłum. Grużewski, s. 315.

${ }^{127}$ Por. tamże XV 3, PG 35, 913.

${ }^{128}$ Tamże XV 10, PG 35, 929, tłum. Grużewski, s. 320.

${ }^{129}$ Por. tamże XV 1-2, PG 35, 912-913.

${ }^{130}$ Po tej linii interpretacyjnej idzie tłumacz Oratio XV - A. Grużewski (s. 321), który przekładając tekst przy słowie „tajemnica” dodał w nawiasie uzupełnienie „Krzyża”. 


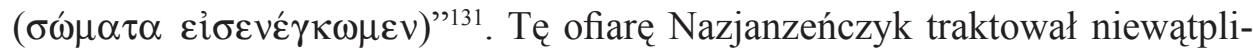
wie w sposób łączny z ofiarą Eleazara, o czym świadczy następujące stwierdzenie: „Ofiara bowiem synów nadzwyczaj posłusznych Prawu i wysoce sprawiedliwych liczy się w poczet zasług ojca" ${ }^{132}$. Stąd też w dalszej części mowy św. Grzegorz wyraźnie stwierdził:

„Ich męstwo podziwiała cała Judea i, jak ona uwieńczona męczeństwem, radowała się i podniosła $\mathrm{z}$ upadku. [...] właśnie przebieg ich męczeństwa był decydujący dla całego narodu hebrajskiego" $" 133$.

Tym decydującym elementem ofiary męczeńskiej dla narodu żydowskiego było oczyszczenie go z dokonanych nieprawości. Męczeńska śmierć męczenników stała się przebłaganiem, które podniosło z upadku Judeę. Widać zatem wyraźnie zbieżność motywów pomiędzy 4Mch a Oratio XV: na plan pierwszy wysuwa się motyw oczyszczenia i w konsekwencji odmiany losu społeczności żydowskiej.

Należy wspomnieć, że w 2Mch w wypowiedzi siódmego z braci machabejskich pojawia się podobny motyw, mianowicie „oddania ciała i duszy za ojczyste prawa" przez męczenników, co było połączone z modlitwą, aby Bóg zatrzymał na nich swój gniew i okazał narodowi żydowskiemu zmiłowanie (por. 2Mch 7, 37-38). Nie ma jednak po pierwsze mowy o oczyszczającym charakterze przelewanej przez męczenników krwi; po drugie - śmierci męczenników w przekazie 2Mch nie należy utożsamiać z ofiarą jako zastępczą wymianą, dzięki której Bóg został ułagodzony ${ }^{134}$. W 4Mch pojawia się natomiast określenie śmierci męczen-

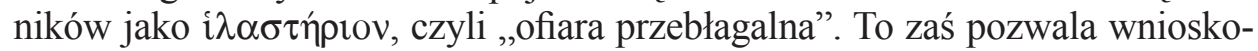
wać, że interpretacja śmierci męczenników, jakiej dokonał św. Grzegorz, idzie bardziej po linii teologicznej 4Mch niż $2 \mathrm{Mch}$. Tę tezę poświadcza również użyte przez obu autorów słownictwo w tym kontekście.

5. Prawo Mojżeszowe jako wychowawca. Bardzo transparentnym elementem wspólnym dla 4Mch i Oratio XV jest koncepcja Prawa jako wychowawcy. W 4Mch w wypowiedzi Eleazara znajduje się apostroficzne wyrażenie $\pi \alpha \imath \delta \varepsilon v \tau \grave{\alpha}$ vó $\mu \varepsilon-$,wychowawco Prawo” (4Mch 5,34), które wprost utożsamia Prawo z wychowawca. Motyw wychowawczej funkcji (w procesie $\pi \alpha 1 \delta \varepsilon i \alpha$ ) Prawa jest również obecny w innych miejscach księgi (por. 4Mch 1, 17; 13, $24)^{135}$. Bardzo ciekawy jest fakt, że św. Grzegorz, komponując mowę matki męczenników, wkłada w jej usta ten sam zwrot, który w 4M 5, 34 wypowiada

${ }^{131}$ Tamże XV 7, PG 35, 924, tłum. Grużewski, s. 318. Por. tamże XV 11, PG 35, 929-932.

${ }^{132}$ Tamże XV 3, PG 35, 913, thum. Grużewski, s. 316.

${ }^{133}$ Tamże XV 11, PG 35, 932, thum. Grużewski, s. 321.

${ }_{134}$ Por. R. Miggelbrink, Gniew Boży. Znaczenie pewnej gorszacej tradycji biblijnej, thum. A. Wałęcki, Myśl Teologiczna 49, Kraków 2005, 79.

${ }^{135}$ Szerzej na ten temat zob. T. Witulski, Das Konzept des vó 441-449. 
Eleazar: $\pi \alpha 1 \delta \varepsilon v \tau \grave{\alpha}$ vó $\mu \varepsilon^{136}$. Ponadto we wcześniejszych partiach Oratio XV pojawia się paralelne wyrażenie w postaci $\pi \alpha 1 \delta \alpha \gamma \omega \gamma o ̀ \varsigma$ vó $\mu$ o - „Prawo-wychowawca"137. Tego rodzaju zbieżność rodzi wniosek, że św. Grzegorz motyw ten zaczerpną z 4Mch, gdyż nie występuje on w $2 \mathrm{Mch}$.

Przy tej okazji należy wspomnieć, że motyw wychowania (por. 4Mch 10, $10 ; 11,15)$, a także związanego $\mathrm{z}$ nim ćwiczenia się $\mathrm{w}$ cnotach, jest obecny zarówno w 4Mch, jak i Oratio XV. Występuje tutaj nawiązanie do procesu kształcenia, jaki dokonywał się w greckim gimnazjonie ${ }^{138}$. W 4Mch 5, 22-24 (por. 13, 21-24) mowa jest o filozofii żydowskiej, która tak wyuczyła

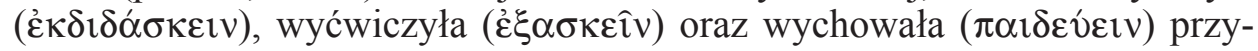
szłych męczenników, że byli w stanie zachować wierność Prawu nawet za cenę życia. A zatem - podobnie jak Grecy w gimnazjonie - tak męczennicy zostali ukształtowani, wychowani i wyćwiczeni ${ }^{139}$ w oparciu o Prawo, stanowiące fundament judaizmu, czyli owej filozofii żydowskiej. Również św. Grzegorz - posługując się podobnym słownictwem - zwrócił uwagę na kwestię wychowania braci machabejskich ${ }^{140}$.

6. Motyw miejsca pochówku męczenników. W obu omawianych dziełach na uwagę zasługuje wzmianka o miejscu pochówku męczenników, czego nie ma w $2 \mathrm{Mch}$. Autor 4Mch co prawda nie wspomniał o konkretnym miejscy pogrzebania męczenników, ale w literacki sposób nakreślił zarys wspólnego grobu z napisem, który mógłby najlepiej odzwierciedlić ich zasługi:

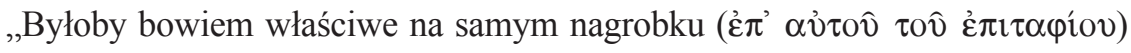
wypisać tym z [naszego] narodu na pamiątkę takie słowa: «Tutaj leżą pogrzebani stary kapłan i stara kobieta oraz siedmiu chłopców, na skutek przemocy tyrana zmierzającego do zniszczenia zasad społeczności Hebrajczyków; obronili oni lud spoglądając ku Bogu i aż do śmierci znosząc męki»” (4Mch 17, 8-10).

Ta literacka konstrukcja autora 4Mch sugeruje, że w czasie, kiedy miała miejsce kompozycja 4Mch, nie istniał żaden uznawany grób męczenników machabejskich $^{141}$. W Oratio XV również nie pojawia się wzmianka o faktycznym grobie męczenników. Św. Grzegorz komponując potencjalne mowy poszcze-

\footnotetext{
${ }^{136}$ Por. Gregorius Nazianzenus, Oratio XV 9, PG 35, 925.

${ }^{137}$ Por. tamże XV 3, PG 35, 916. Należy zaznaczyć, że zarówno termin $\pi \alpha \imath \delta \alpha \gamma \omega \gamma o ́ s$, jak i $\pi \alpha 1 \delta \varepsilon v \tau \dot{n}$ s mają m.in. znaczenie ,nauczyciel, wychowawca”.

${ }^{138}$ Por. Słapek, Sport $i$ widowiska, s. 281-285.

${ }^{139} \mathrm{~W} 2 \mathrm{Mch} 7,27$ pojawia się również zagadnienie wychowania, nie występuje jednakże motyw $\pi \alpha i \delta \varepsilon i ́ \alpha$.

${ }^{140}$ Por. Gregorius Nazianzenus, Oratio XV 2, PG 35, 913; XV 3, PG 35, 913.

${ }^{141}$ Por. Wojciechowski, Apokryfy z Biblii greckiej, s. 194. M. Hadas (The Third and Fourth Books of Maccabees, s. 234) stwierdza natomiast, że owa wzmianka dotycząca grobu i napisu może być brana jako dowód, że 4Mch była przeznaczona do wygłoszenia w miejscu, w którym rzeczywiście był grób męczenników. To wygłoszenie mowy mogło mieć miejsce w czasie uroczystości obchodzonej dla uczczenia pamięci męczenników. Jednakże ze względu na retoryczny charakter
} 
gólnych męczenników, w ich usta włożył jedynie życzenie odnoszące się do wspólnego pochowku. Pierwsza wzmianka o tym występuje w mowie przypisanej ogólnie braciom męczennikom:

„Jeruzalem, pochowaj nas zmarłych wspaniale, jeśli coś pozostanie do pochowania, opowiadaj o naszych czynach i pokazuj potomnym i twoim miłośnikom czczony grobowiec wielu mężów, pochodzących z jednego łona"142.

Druga wzmianka została wyrażona ustami matki siedmiu braci: „niech wspólny grób nas przyjmie!"143. Jakkolwiek przywołane fragmenty przynależą do literackich, zretoryzowanych konstrukcji, to jednak warto zwrócić uwagę na dwa szczegóły. Po pierwsze na wzmiankę o wspólnym grobie męczenników. Zasadniczo w przypadku Oratio XV chodzi o wspólny pochówek siedmiu barci i ich matki; brak u św. Grzegorza bezpośredniego nawiązania do wspólnego grobu wraz z Eleazarem, jak to jest w 4Mch. Drugi szczegół to wyakcentowanie Jerozolimy jako miejsca pochówku. W tym kontekście rodzi się pytanie, czy wzmianka ta - obecna w ramach literackiej kompozycji - posiada w zamierzeniach św. Grzegorza jakiekolwiek odniesienie do historycznych realiów, to znaczy, do realnego miejsca pochówku w Jerozolimie?

7. Wspólne odniesienia biblijne. Pewnym punktem wspólnym pomiędzy 4Mch a Oratio XV mogą być bezpośrednie odwołania do starotestamentalnych motywów biblijnych w ramach opisu męczeństw. Dla lepszego zobrazowania zostaną one przedstawione $\mathrm{w}$ tabeli:

\begin{tabular}{|l|l|l|}
\hline $\begin{array}{l}\text { Ofiarowanie Izaaka przez Abra- } \\
\text { hama (por. Rdz 22, 1-14) }\end{array}$ & Oratio XV 4, PG 35, 916 & $\begin{array}{l}\text { 4Mch 7, 14; 14, 20; 15, } \\
28 ; 17,6 ; 18,11\end{array}$ \\
\hline $\begin{array}{l}\text { Daniel w jaskini lwów (por. Dn } \\
\text { 6, 1-28) }\end{array}$ & $\begin{array}{l}\text { Oratio XV 6, PG 35, 921; } \\
\text { XV 11, PG 35, 932 }\end{array}$ & 4Mch 16, 3. 21; 18, 13 \\
\hline $\begin{array}{l}\text { Ananiasz, Azariasz i Miszael } \\
\text { w piecu ognistym (por. Dn 3) }\end{array}$ & $\begin{array}{l}\text { Oratio XV 6, PG 35, 921; } \\
\text { XV 11, PG 35, 932 }\end{array}$ & $\begin{array}{l}\text { 4Mch 13, 9; 16, 3. 21; 18, } \\
12\end{array}$ \\
\hline $\begin{array}{l}\text { Motyw gorliwego Pinchasa (Fi- } \\
\text { neasa) (por. Lb 25, 7-13) }\end{array}$ & Oratio XV 9, PG 35, 928 & 4Mch 18, 12 \\
\hline
\end{tabular}

Należy wspomnieć, że w relacji męczeństwa Eleazara oraz siedmiu braci i ich matki autor 2Mch posłużył się jedynie jednym cytatem starotestamentalnym, który został zaczerpnięty z Pwt $32,36^{144}$. W Oratio XV nie pojawia się jednak żadne odniesienie do tegoż cytatu.

\footnotetext{
4Mch owa wzmianka nie musi być ostatecznym dowodem potwierdzającym istnienie wspomnianego grobu męczenników.

${ }^{142}$ Gregorius Nazianzenus, Oratio XV 7, PG 35, 924, thum. Grużewski, s. 319.

${ }^{143}$ Tamże XV 9, PG 35, 928, thum. Grużewski, s. 320.

${ }^{144}$ Por. F. Gryglewicz, Księgi Machabejskie. Wstęp-przekład z oryginatu-komentarz, Pismo Święte Starego Testamentu VI/4, Poznań 1961, 305.
} 
8. Doksologia końcowa. Na szczególną uwagę zasługuje zbieżność zakończenia obu omawianych dzieł. To zakończenie ma postać doksologii, która posiada tę samą formułę:

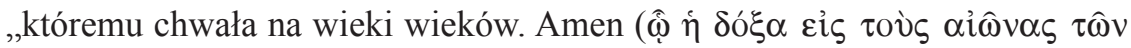

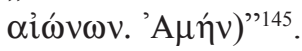

Doksologie o takim samym brzmieniu występują również w Nowym Testamencie (por. Ga 1, 5; Flp 4, 20; 1Tm 1, 17; 2Tm 4, 18; Hbr 13, 21) ${ }^{146}$. Istnieje sugestia, że Nowy Testament tego rodzaju doksologię mógł zaczerpnąć z $4 \mathrm{Mch}^{147}$. Wydaje się jednak, że jej genezy należy szukać we wspólnym źródle żydowskiej pobożności ${ }^{148}$, która z kolei bardzo mocno osadzona jest w tradycji starotestamentalnej teologii ${ }^{149}$.

Analizując zakończenie 4Mch, można zauważyć, że owa chwała - z racji oczywiście żydowskiego charakteru dzieła - jest przypisana bezpośrednio samemu Bogu (por. 4Mch 18, 23). W przypadku zaś doksologii św. Grzegorza trudno jednoznacznie orzec, czy posiada ona charakter teocentryczny czy chrystocentryczny. Trudność ta wynika z poprzedzającego wywodu, zakończonego wzmianką imienia Chrystusa, po którym bezpośrednio następuje zaimek względny $\hat{\hat{\omega}}$ :

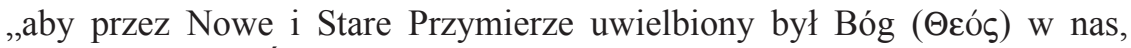
w Synu i Duchu Świętym, On który zna swoich i przez swoich jest znany; wyznawany i wyznający, sławiony i sławiący w samym Chrystusie ( $\dot{\varepsilon} \nu \alpha \hat{\tau} \tau \hat{\omega}$

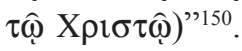

Wydaje się jednak, że - jak w przypadku Hbr 13, 20-21 oraz 1P 4, 11 - ak-

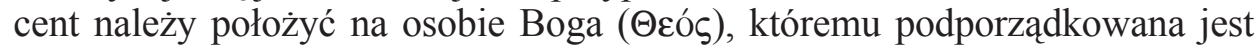
doksologia $^{151}$. Rodzi się oczywiście pytanie, czy 4Mch była bezpośrednią inspiracją dla św. Grzegorz, aby po pierwsze zakończyć mowę doksologia, po drugie zaś - posłużyć się taką samą formułą jak w 4Mch. Pierwszorzędnie należy zauważyć, że większość mów św. Grzegorz zakończona jest doksologią. Te doksologie mają różną postać; pośród nich można znaleźć jednak również i taką formę, która jest identyczna z występującą w Oratio XV ${ }^{152}$. Stąd też rodzi

\footnotetext{
${ }^{145}$ Gregorius Nazianzenus, Oratio XV 12, PG 35, 933, tłum. Grużewski, s. 322. Por. 4Mch 18, 24.

${ }^{146} \mathrm{~W}$ Nowym Testamencie pojawiają się również doksologie o podobnym brzmieniu: Rz 11, 36; 16, 27; Ef 3, 21; 1P 5, 11; 2P 3, 18; Jud 1, 25; Ap 1, 6.

${ }^{147}$ Por. P. Staples, The Unused Lever? A Study on the Possible Literary Influence of the Greek Maccabean Literature in the New Testament, „Modern Churchman” 9 (1966) 221-222.

${ }^{148}$ Por. Wojciechowski, Apokryfy z Biblii greckiej, s. 200.

${ }^{149}$ Por. A. Suski, U źródet doksologii, StPł 2 (1974) 8-12.

${ }^{150}$ Gregorius Nazianzenus, Oratio XV 12, PG 35, 933, thum. Grużewski, s. 322.

${ }^{151}$ Por. Suski, Uźródet doksologii, s. 14.

${ }^{152}$ Taka sama doksologia jak w Oratio XV pojawia się również w: Oratio VII 24, PG 35, 788;

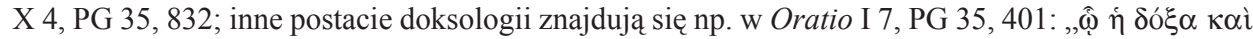

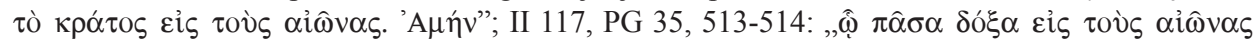


się wniosek, że św. Grzegorz niekoniecznie kierował się motywem doksologii końcowej z 4Mch. Ogólna praktyka stosowania doksologii w zakończeniu mów, która pojawia się również u innych pisarzy chrześcijańskich tamtego okresu $^{153}$, była co do treści inspirowana z pewnością tekstami biblijnymi Nowego Testamentu, a także praktyką liturgiczną. Stąd też trudno uznać obecność doksologii w Oratio XV za bezpośredni wpływ 4Mch na św. Grzegorza. Być może jedynie - aczkolwiek jest to daleko posunięta hipoteza - sama forma/ kształt użytej przez Nazjanzeńczyka doksologii była inspirowana 4Mch.

Celem artykułu było wykazanie, że św. Grzegorz z Nazjanzu komponując Oratio XV sięgał do tekstu 4Mch. Taki wniosek z pewnością może się wstępnie zrodzić znawcom 4Mch już po pobieżnej lekturze Oratio XV. Potwierdzeniem tej tezy są przedstawione wyżej wyniki analiz, które pozwalają zauważyć, że na wielu płaszczyznach występują wyraźne zbieżności pomiędzy 4Mch a Oratio XV. Pierwszą z nich jest określony przez Nazjanzeńczyka temat dzieła, które prezentuje dzieje męczenników - Eleazara, siedmiu braci i ich matki, a na którym to dziele oparł się św. Grzegorz. Kolejnym punktem stycznym wydaje się być powielenie przez św. Grzegorza pewnych nieścisłości historycznych, które są również obecne w 4Mch. Na uwagę zasługuje także sposób przedstawiania męczenników przez św. Grzegorza: użyte przez Nazjanzeńczyka określenia, poszczególne motywy mogą świadczyć, że materiałem źródłowym dla niego była $4 \mathrm{Mch}$. Postawioną w tytule tezę z pewnością potwierdza występujący w Oratio XV motyw ofiary męczenników, mającej charakter oczyszczenia Izraela z grzechu. Tego rodzaju motyw pojawia się wyraźnie w 4Mch. Również przywołane w Oratio XV nazwy narzędzi tortur wydają się sugerować, że Nazjanzeńczyk korzystał z tekstu 4Mch. Podobnie rzecz się ma z metaforyką agonistyczno-militarną, zastosowaną do opisu męczeństwa, określeniem Prawa jako wychowawcy, czy też pojawiającymi się odniesieniami biblijnymi. Należy jeszcze zaznaczyć, że obydwa dzieła posiadają wyraźny element parenetyczny ${ }^{154}$. Przedstawione zatem wyniki analiz nie pozostawiają złudzeń, że św. Grzegorz korzystał z tekstu 4Mch przy komponowaniu swego dzieła. A zatem nie posłużył się kanoniczną 2Mch, ale skorzystał z apokryficznego opracowania historii męczeństwa Eleazara oraz siedmiu braci i ich matki. Fakt ten jest świadectwem, że w czasach św. Grze-

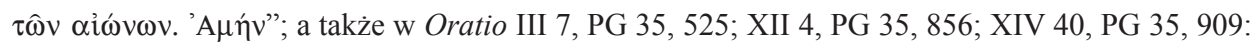

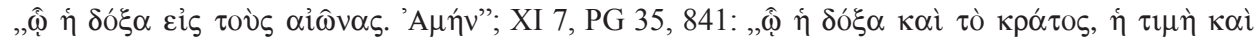

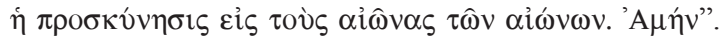

${ }^{153}$ Por. np. Basilius Caesariensis, De ieiunio hom. II 8, 4, PG 31, 197; tenże, Homilia in martyrem Julittam 9, 1, PG 31, 261; tenże, Sermo de ascetica disciplina 2, 41, PG 31, 652; Joannes Chrysostomus, In Genesim ser. 4, 2, 658, PG 54, 593.

${ }^{154}$ Por. Gregorius Nazianzenus, Oratio XV 12, PG 35, 933. Zob. 4Mch 18, 1-2. 
gorz z Nazjanzu 4Mch cieszyła się dość dużą popularnością oraz uznaniem wśród chrześcijan Kapadocji.

\section{THE FOURTH BOOK OF THE MACCABEES AS BACKGROUND OF ORATIO XV BY ST. GREGORY OF NAZIANZEN}

\section{(Summary)}

Based on a comparative analysis of $4 \mathrm{Mac}$ and Oratio $\mathrm{XV}$, it can be noted that St. Gregory - when composing the speech in honor of the martyrs - used mostly apocryphal work depicting history of the martyrdom of Eleazar as well as of the seven brothers and their mother rather than the canonical 2Mac. This is evidenced by quite clear convergence of both works: their authors use the same vocabulary to characterize their heroes and describe the instruments of torture; they employ the same agonist-military metaphors; they include the motive of martyrs' death as a sacrifice purifying the Jewish people etc. The fact that St. Gregory used 4Mac in composing Oratio XV can evidence quite high popularity and reputation that 4Mac enjoyed among Christians of Cappadocia in his time (i.e. in $4^{\text {th }}$ century).

Key words: The Fourth Book of the Maccabees, St. Gregory Nazianzen, In Machabaeorum laudem.

Słowa kluczowe: Czwarta Księga Machabejska, św. Grzegorz z Nazjanzu, Pochwała Machabejczyków.

\section{BIBLIOGRAFIA}

\section{Źródła}

Eusebius Caesariensis, Historia Ecclesiastica, wyd. grecko-polskie, oprac. H. Pietras, tłum. A. Caba na podstawie tłum. A. Lisieckiego, ŹMT 70, Kraków 2013.

Hieronymus, De viris illustribus, PL 23, 601-720, tłum. W. Szołdrski: Św. Hieronim, O znakomitych mężach, PSP 6,Warszawa 1970, 23-159.

Gregorius Nazianzenus, Oratio XV: In Machabaeorum laudem, PG 35, 912-933, tłum. A. Grużewski: Św. Grzegorz z Nazjanzu, Mowa 15: Pochwała Machabejczyków, w: J.M. Szymusiak, Grzegorz Teolog. U źródet chrześcijańskiej myśli IV wieku, Poznań 1965, 315-322.

Machabaeorum IV, ed. A. Rahlfs, w: Septuaginta. Id est Vetus Testamentum graece iuxta LXX interpretes, t. 1, Stuttgart 1979, 1157-1184, thum. M. Wojciechowski: Czwarta Księga Machabejska, w: M. Wojciechowski, Apokryfy z Biblii greckiej. 3 i 4 Księga Machabejska, 3 Księga Ezdrasza, oraz Psalm 151 i Modlitwa Manassesa, Rozprawy i Studia Biblijne 8, Warszawa 2001, 123-200.

Martyrologium Romanum. Ex Decreto Sacrosncti Oecumenici Concilii Vaticani II Instauratur Auctoritate Ioannis Pauli PP II Promulgatum. Editio Typica, Typis Vaticanis 2001. 


\section{Opracowania}

BARAn G.M., Baptyzmalny charakter ,powtórnego narodzenia” w Tradycji Janowej, Lublin 2008 (mps, Archiwum KUL).

Baran G.M., Kobiety w kulturze i religii społeczności żydowskiej w świetle Ksiag Machabejskich, „Studia Ełckie” 16 (2014) 419-456.

Baran G.M., The Jewish Community and the Hellenistic Culture in the Light of the Books of the Maccabees, „Teologia i Człowiek” 25 (2014) nr 1, 55-78.

BARAN G.M., Życie i śmierć Antiocha IV Epifanesa w przekazach pozabiblijnych i biblijnych. Historia i teologia, Tarnów 2015.

Breitenstein U., Beobachtungen zu Sprache, Stile und Gedankengut des Vierten Makkabäerbuchs, Basel - Stuttgart 1976.

Cummins S.A., Paul and Crucified Christ in Antioch. Maccabean Martyrdom and Galatians 1 and 2, Society for New Testament Studies. Monograph Series 114, Cambridge 2004.

Doran R., 2 Maccabees. A Critical Commentary, Hermeneia - A Critical and Historical Commentary on the Bible, Minneapolis 2012.

GĄssowska B., Wieniec, w: Stownik kultury antycznej, red. R. Kulesza, Warszawa 2012, 511.

Hadas M., The Third and Fourth Books of Maccabees, Jewish Apocryphal Literature, New York 1953.

JuREwicz O., Stownik grecko-polski, t. 1-2, Warszawa 2000-2001.

KLAUCK H.J., 4. Makkabäerbuch, Jüdische Schriften aus hellenistisch-römischer Zeit III/6, Gütersloh 1989.

Klauck H.J., Hellenistische Rhetorik im Diasporajudentum. Das Exordium des vierten Makkabäerbuchs (4 Makk 1.1-12), NTS 35 (1989) 451-465.

Korolko M., Sztuka retoryki. Przewodnik encyklopedyczny, Warszawa 1990.

Kraus RegGiani C., 4 Maccabei, Commentario storico ed esegetico all'Antico e al Nuovo Testamento 1, Genova 1992.

Miggelbrink R., Gniew Boży. Znaczenie pewnej gorszacej tradycji biblijnej, thum. A. Wałęcki, Myśl Teologiczna 49, Kraków 2005.

Oberman J., The Sepulchre of the Maccabean Martyrs, JBL 50 (1931) 250-265.

ReneHan R., The Greek Philosophical Background of Forth Maccabees, „Rheinisches Museum für Philologie" 115 (1972) 223-238.

Ryken L. - Wilhoit J.C., Stownik symboliki biblijnej. Obrazy, symbole, motywy, metafory, figury stylistyczne i gatunki literackie w Piśmie Świętym, tłum. Z. Kościuk, Prymasowska Seria Biblijna, Warszawa 1998.

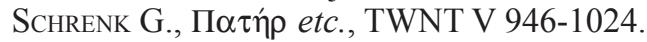

Silva D.A. DE, 4 Maccabees, Guides to Apocrypha and Pseudepigrapha, Sheffield 1998.

Sinko T., De Gregorii Nazianzei Laudibus Machabaeorum, „Eos” 13 (1907) 1-29.

SŁAPEK D., Sport i widowiska w świecie antycznym, Kraków - Warszawa 2010.

Stownik grecko - polski, red. Z. Abramowiczówna, t. 1-4, Warszawa 1958-1965.

Staples P., The Unused Lever? A Study on the Possible Literary Influence of the Greek Maccabean Literature in the New Testament, „Modern Churchman” 9 (1966) 218-224.

SusKi A., U źródet doksologii, StPł 2 (1974) 7-16.

Szymusiak J.M., Grzegorz Teolog. U źródeł chrześcijańskiej myśli IV wieku, Poznań 1965. Święty Grzegorz z Nazjanzu. Mowy wybrane, red. S. Kazikowski, Warszawa 1967.

Witulski T., Das Konzept des vó

Wosciechowski M., Apokryfy z Biblii greckiej. 3 i 4 Księga Machabejska, 3 Księga Ezdrasza, oraz Psalm 151 i Modlitwa Manassesa, Rozprawy i Studia Biblijne 8, Warszawa 2001.

Zawiszewski E., Księgi Machabejskie, w: Wstęp do Starego Testamentu, red. L. Stachowiak, Poznań 1990, 227-234. 